FLAVIA RABELO FRAYHA DE SOUZA

\title{
Avaliação do teste de contato atópico na alergia ao leite de vaca IgE mediada e nas doenças eosinofílicas ao trato
} digestório

\author{
Dissertação apresentada à Faculdade de Medicina \\ da Universidade de São Paulo para obtenção do título \\ de Mestre em Ciências
}

Programa de Pediatria

Orientadora: Prof ${ }^{a}$ Dra. Cristina Miuki Abe Jacob

São Paulo 
Dados Internacionais de Catalogação na Publicação (CIP)

Preparada pela Biblioteca da

Faculdade de Medicina da Universidade de São Paulo

Creprodução autorizada pelo autor

\section{Frayha-Souza, Flavia Rabelo}

Avaliação do teste de contato atópico na alergia ao leite de vaca IgE mediada e nas doenças eosinofílicas do trato digestivo / Flavia Rabelo Frayha de Souza. -São Paulo, 2011.

Dissertação(mestrado)--Faculdade de Medicina da Universidade de São Paulo. Programa de Pediatria.

Orientador: Cristina Miuki Abe Jacob

Descritores: 1.Hipersensibilidade alimentar 2.Esofagite eosinofílica 3.Enterite 4.Leite de vaca 5.Diagnóstico 6.Testes cutâneos 7.Criança 8.Adolescente

USP/FM/DBD-356/11 
"Que os vossos esforços desafiem as impossibilidades, lembrai-vos de que as grandes coisas do homem foram conquistadas do que parecia impossível".

Charles Chaplin 


\section{DEDICATÓRIA}

Aos meus queridos pais, Cláudio e Graziela, a quem devo minha formação e eterna gratidão pelo amor, estímulo e apoio, além do exemplo de dedicação à educação dos filhos.

Ao meu querido marido André, pela compreensão e companheirismo, frutos da maturidade de um grande amor.

À minha amada filha Giovanna, que é a fonte de amor e inspiração e que torna as nossas vidas ainda mais especiais. 


\section{DEDICATÓRIA}

Aos meus queridos irmãos Gustavo e Eduardo, ao amor que nos une sempre e ao apoio de uma forma descontraída e com humor que traz conforto e serenidade.

Às minhas queridas cunhadas Nádia e Mariana e ao meu amado sobrinho e afilhado Enrico pelo apoio e torcida e por fazerem parte da nossa família. 


\section{AGRADECIMENTOS}

À querida orientadora Profa Dra. Cristina Miuki Abe Jacob, exemplo de dedicação à ciência e ao ensino, sou eternamente grata por todas as oportunidades e pelo aprendizado durante todos estes anos. Agradeço o incentivo e carinho ao longo desta dissertação.

Ao querido $\operatorname{Dr}$ Antônio Carlos Pastorino, obrigada pelo apoio, pela disponibilidade em ensinar e pelas orientações em análises de dados.

À querida amiga e anjo da guarda Dra Ana Paula Moschione Castro, a quem admiro muito, agradeço seu carinho, apoio e incentivo.

À querida Dra Ângela Bueno Ferraz Fomin, pelo incentivo e apoio.

À querida amiga Luciana Ribeiro, companheira de pós graduação, pelo estímulo, apoio e orientações.

Às amigas do Ambulatório de Alergia Alimentar, Andréa Gushken, Cleonir Beck, Mayra Dorna, Glauce Hiromi Yonamine, Ana Cláudia Brandão, Letícia Watanabe, Marcela Odaira, pelos conselhos, estímulo e amizade ao longo destes anos.

Ao grupo de Alergia e Imunologia, complementandos atuais e excomplementandos, pelo trabalho em equipe e incentivo à realização deste trabalho.

Ao Prof. Ulysses Doria Filho, pelo importante auxílio durante a análise dos dados. 


\section{AGRADECIMENTOS}

À querida amiga Renata Melo, companheira desde a residência, sempre incentivadora com grande humor.

À equipe multiprofissional de enfermeiras, auxiliares, nutricionistas sempre disponíveis a colaborar com o trabalho.

À IPI - ASAC Espanha e Brasil representada pelo Dr Mori e pelo Eliomar, agradeço a disponibilidade da doação dos testes e pela prontidão à qualquer solicitação de material.

À bibliotecária Mariza K. U. Yoshikawa, pela contribuição na revisão bibliográfica e pela disponibilidade em me ajudar.

Às secretárias do Departamento de Pediatria do Instituto da Criança, em especial à Adriana Bezerra e à Mônica Souza, pela disponibilidade e apoio.

Ao Nivaldo e Milena Rocha, pelo carinho e por estarem sempre prontos a nos ajudar nos momentos finais da dissertação.

À CAPES, pela bolsa de pesquisa concedida para a realização deste estudo. 


\section{AGRADECIMENTOS ESPECIAIS}

À Deus, por sempre me guiar e abençoar. Sou eternamente grata.

À minha querida família pelo apoio e torcida.

Aos meus queridos sogros João Bosco e Rita e ao meu cunhado João, pelo carinho, compreensão e apoio.

Às secretárias Márcia, Rose, Cinthia, pelo incentivo, paciência e compreensão.

Aos pacientes e seus familiares pela confiança e disponibilidade na participação do estudo. 
Esta dissertação está de acordo com as seguintes normas, em vigor no momento desta publicação:

Referências: adaptado de International Committee of Medical Journals Editors (Vancouver)

Universidade de São Paulo. Faculdade de Medicina. Serviço de Biblioteca e Documentação. Guia de apresentação de dissertações, teses e monografias. Elaborado por Anneliese Carneiro da Cunha, Maria Júlia de A.L. Freddi, Maria F. Crestana, Marinalva de Souza Aragão, Suely Campos Cardoso, Valéria Vilhena. $2^{a}$ de. São Paulo: Serviço de Biblioteca e Documentação; 2005.

Abreviaturas dos títulos dos periódicos de acordo com List of Journals Indexed in Index Medicus 


\section{Sumário}

Lista de Abreviaturas e Siglas

Lista de Quadros e Figuras

Lista de Tabelas

Lista de Anexos

Resumo

Summary

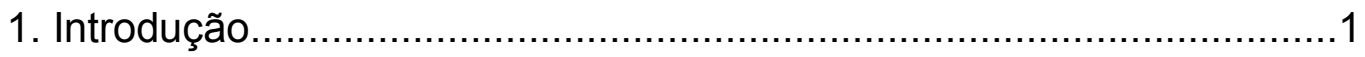

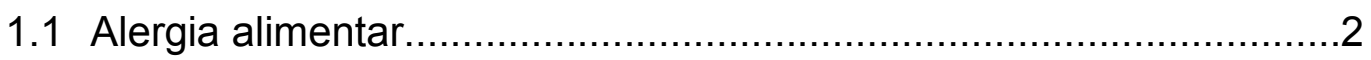

1.2 Alergia às Proteínas do Leite de Vaca.......................................5

1.3 Manifestações Clínicas da Alergia à Proteína Do Leite de Vaca.......6

1.3.1. Manifestações Clínicas IgE mediadas ....................................6

1.3.2. Manifestações Clínicas Não lgE mediada..................................7

1.3.3. Manifestações Mistas.......................................................

1.3.3.1. Esofagite Eosinofílica...................................................... 8

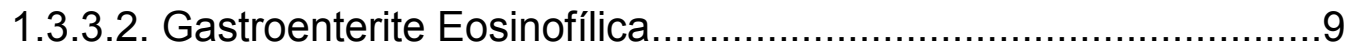

1.4 Diagnóstico de Alergia às Proteínas do Leite de Vaca...................10

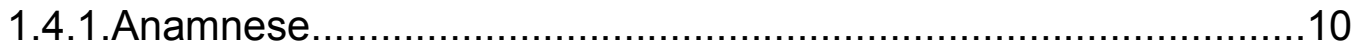

1.4.2.Exames complementares............................................. 10

1.4.2.1.Prick Teste............................................................. 11

1.4.2.2.Pesquisa de $\operatorname{lgE}$ sérica específica...................................11

1.4.2.3.Testes de provocação oral..............................................12

1.4.2.4.Teste de Contato Atópico (TCA) …..................................................13 
1.4.2.4.1 Técnica para a realização do TCA.........................................15

1.4.2.4.2. Interpretação do TCA para alimentos .................................... 16

1.4.2.4.3. A aplicação do TCA na Esofagite Eosinofílica......................... 17

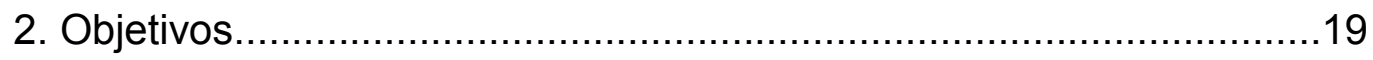

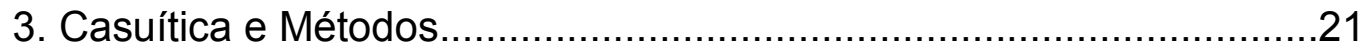

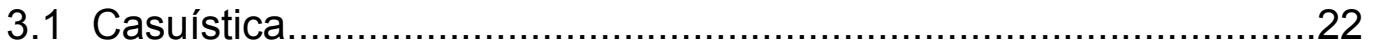

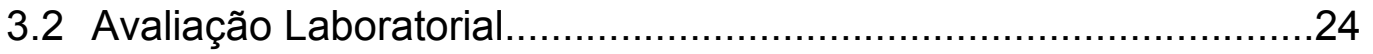

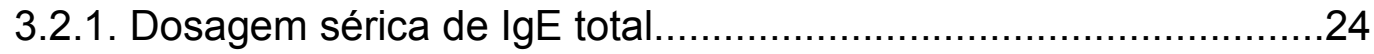

3.2.2. Dosagem sérica de IgE específica in vitro (ImmunoCAP®) ..........24

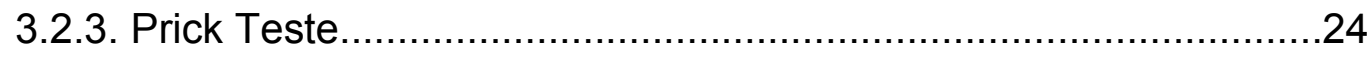

3.2.4. Teste de Provocação Duplo Cego Placebo Controlado..................24

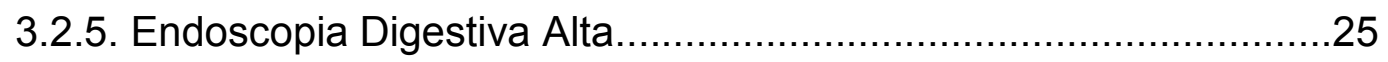

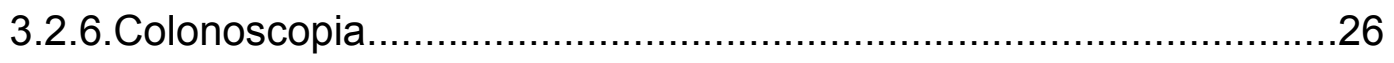

3.3.Avaliação do Teste de Contato Atópico...............................................26

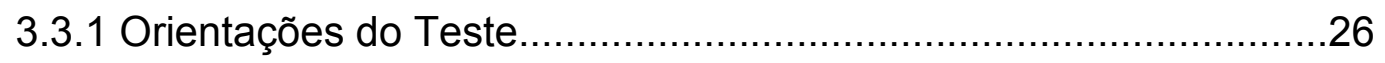

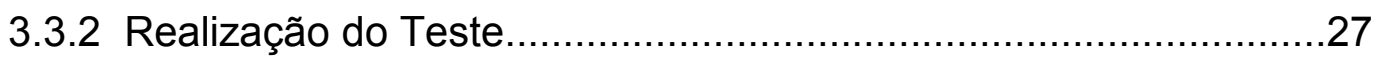

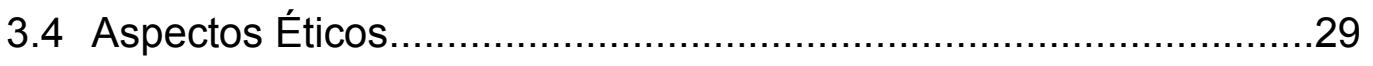

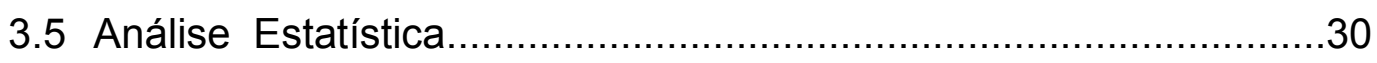

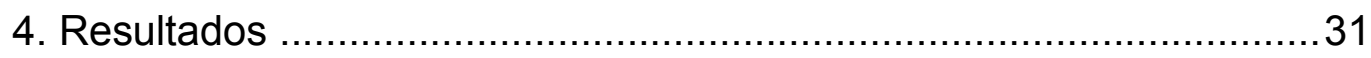

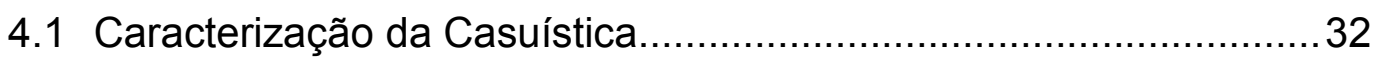

4.2 Resultados do Teste de Contato Atópico........................................... 34

4.3. Avaliação da melhora clínica e endoscópica dos pacientes com Doenças Eosinofílicas do Trato Digestório (DETD) após exclusão do leite de vaca sugerido pelo TCA....................................................

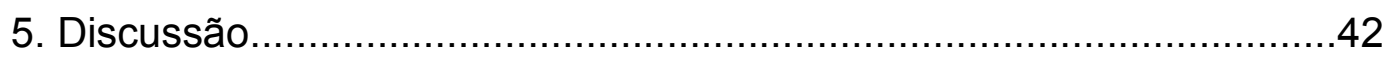

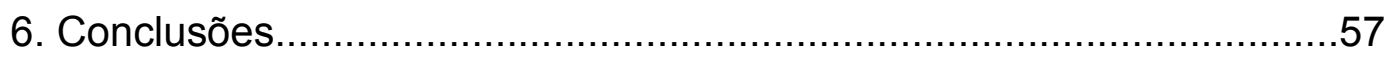


7. Anexos.

8. Referências. 


\section{LISTA DE ABREVIATURAS E SIGLAS}

\begin{tabular}{|c|c|}
\hline$A A$ & - Alergia Alimentar \\
\hline APLV & - Alergia às Proteínas do Leite de Vaca \\
\hline TCA & - Teste de Contato Atópico \\
\hline EoE & - Esofagite Eosinofílica \\
\hline DETD & - Doença Eosinofílica do Trato Digestório \\
\hline ICr-HCFMUSP & $\begin{array}{l}\text { - Instituto da Criança do Hospital das Clínicas da } \\
\text { Faculdade de Medicina da Universidade de São Paulo }\end{array}$ \\
\hline $\lg \mathrm{E}$ & - Imunoglobulina $\mathrm{E}$ \\
\hline LV & - Leite de vaca \\
\hline RAST & - Radioimmunoallergosorbent Test \\
\hline TPODCPC & $\begin{array}{l}\text { - Teste de Provocação Oral Duplo Cego Placebo } \\
\text { Controlado }\end{array}$ \\
\hline EAACl & - European Academy of Allergy and Clinical Immunology \\
\hline ETFAD & - European Task Force on Atopic Dermatitis \\
\hline Th1 & - Célula T helper 1 \\
\hline Th2 & - Célula T helper 2 \\
\hline FPIES & $\begin{array}{l}\text { - Síndrome da enterocolite induzida por proteínas do } \\
\text { alimento }\end{array}$ \\
\hline $\mathrm{Dp}$ & - Dermatophagoides pteronyssinus \\
\hline IL & - Interleucina \\
\hline SAO & - Síndrome da alergia oral \\
\hline cga & - Campo de grande aumento \\
\hline DA & - Dermatite atópica \\
\hline
\end{tabular}




\section{LISTA DE QUADROS E FIGURA}

Quadro 1 - Características das diversas metodologias empregadas no

TCA em alergia alimentar nos diversos estudos publicados. 16

Quadro 2 - Proposta para leitura do TCA segundo European Task Force on Atopic Dermatitis (ETFAD), 2003

Quadro 3 - Leitura do Teste de Contato Atópico - European Task Force on Atopic Dermatitis (ETFAD) .29

Figura 1- Material utilizado no TCA 


\section{LISTA DE TABELAS}

Tabela 1 - Dados demográficos e presença de atopia pessoal e familiar dos pacientes dos grupos 1, 2 e 3

Tabela 2 - Concentração sérica de IgE total e específica para leite e/ou frações e teste de provocação oral duplo cego placebo controlado dos pacientes dos grupos 1,2 e 3

Tabela 3 - Comparação entre o extrato de leite de vaca a 20\% e/ou leite de vaca in natura em relação à freqüência de positividade do TCA nos pacientes com APLV IgE mediada, nos 3 tempos de leitura avaliados 34

Tabela 4 - Comparação entre o extrato de leite de vaca a 20\% e/ou leite de vaca in natura em relação à freqüência de positividade do TCA nos pacientes com DETD, nos 3 tempos de leitura avaliados

Tabela 5 - Concordância entre os tempos de leitura do TCA do TCA com o extrato de leite de vaca a $20 \%$ e/ou leite de vaca in natura nos pacientes com APLV IgE mediada.

Tabela 6 - Concordância entre os tempos de leitura do TCA com o extrato de leite de vaca a $20 \%$ e lou leite de vaca nos pacientes com DETD

Tabela 7- Concordância entre os tempos de leitura do TCA com o extrato de leite de vaca a $20 \%$ nos pacientes com APLV IgE mediada

Tabela 8 - Concordância entre os tempos de leitura do TCA com o extrato de leite de vaca a $20 \%$ nos pacientes com DETD

Tabela 9 - Concordância entre os tempos de leitura do TCA com o leite in natura nos pacientes com APLV IgE mediada 
Tabela 10 - Concordância entre os tempos de leitura do TCA com o leite in natura nos pacientes com DETD.

Tabela 11- Descrição das reações adversas ocorridas durante a aplicação e leituras do TCA nos pacientes com APLV IgE mediada e nas DETD. 39

Tabela 12- Descrição da melhora clínica e histológica em vinte pacientes com DETD com TCA positivo após 3 meses de exclusão do leite.................40 


\section{LISTA DE ANEXOS}

Anexo A - Aprovação do estudo pela Comissão de Ética para análise de projetos de pesquisa do Hospital das Clínicas FMUSP

Anexo B - Protocolo Padronizado para o Teste de Contato Atópico

Anexo C - Impresso com o resultado do Teste de Contato Atópico

Anexo D - Orientações para realização do Teste de Contato Atópico

Anexo E - Orientações durante e após a realização do Teste de Contato Atópico 65

Anexo F - Termo de Consentimento Livre e Esclarecido. 66

Anexo G - Valores de IgE específica para leite de vaca, $\alpha$ lactoalbumina, $\beta$ lactoglobulina e caseína em pacientes com alergia às proteínas do leite de vaca IgE mediada 69

Anexo $\mathbf{H}$ - Valores de lgE específica para leite de vaca, $\alpha$ lactoalbumina, $\beta$ lactoglobulina e caseína em pacientes com Doenças Eosinofílicas do Trato Digestório .70 


\section{RESUMO}

Frayha-Souza FR. Avaliação do Teste de Contato Atópico na Alergia ao Leite de Vacamediada por IgE e nas Doenças Eosinofílicas do Trato Digestório. (Dissertação). São Paulo: Faculdade de Medicina da Universidade de São Paulo; 2011.

Objetivo: Avaliar o teste de contato atópico (TCA) em pacientes com alergia ao leite de vaca (APLV) IgE mediada - grupo 1 e naqueles com doenças eosinofílicas do trato digestório (DETD) - grupo 2, comparando os extratos de leite de vaca (LV) a $20 \%$ com o leite in natura, o tempo ideal de oclusão do teste e o valor preditivo positivo do TCA na identificação do leite como desencadeante no grupo 2, avaliada pela melhora clinica e endoscópica após dieta de restrição. Métodos: Estudo de corte transversal, com avaliação de 45 pacientes e 9 controles. O grupo $1(n=15)$ com APLV IgE mediada foram diagnosticados pelo teste de provocação e prick teste positivo para LV e o grupo $2(n=30)$ pela biópsia mostrando esofagite eosinofílica ( $\geq 15$ eosinófilos/cga) ou enterocolite eosinofílica $(\geq 20$ eosinófilos/cga), prick teste positivo para LV $(n=15)$ e sintomas desencadeados pelo leite. O grupo $3(n=9)$ incluiu pacientes com exclusão do diagnóstico de APLV. Utilizou-se câmaras de $12 \mathrm{~mm}$ e LV in natura e LV a $20 \%$ como extratos (IPI ASAC, Espanha). Os tempos de leitura foram de 24, 48 e 72 horas e considerou-se como TCA positivo, a presença de hiperemia com infiltração e formação de pápulas ou vesículas. Para avaliação do valor preditivo positivo do TCA, considerou-se pacientes com DETD com sintomas associados ao leite, sem melhora com tratamento adequado, IgE específica ao LV e melhora clínica e histológica com a instituição da dieta de restrição.

Resultados: Considerando ambos os extratos, houve semelhança quanto à frequência de positividade do TCA nos três tempos de leitura em ambas situações clínicas. Com relação à concordância entre os tempos de leitura do TCA com ambos extratos, observou-se diferença estatisticamente significante entre o tempo de 24 hs com aqueles de 48 e 72hs ( $p=0,031$ em ambas comparações), o mesmo não ocorrendo entre o tempo de 48 e $72 \mathrm{hs}$ 
tanto na APLV como nas DETD. Isoladamente, o LV a $20 \%$ mostrou comportamento semelhante em ambas as doenças, com diferença entre $\mathrm{O}$ tempo de 24 e aqueles de $48(p=0,031 / 0,000)$ e 72hs $(p=0,031 / 0,002)$ respectivamente na APLV e DETD. O extrato de leite in natura nos pacientes com APLV não mostrou diferença estatisticamente significante entre os tempos avaliados, enquanto nos pacientes com DETD observou-se diferença entre $24 \mathrm{hs}$ e os tempos de $48 \mathrm{hs}(\mathrm{p}=0,003)$ e $72 \mathrm{hs}(\mathrm{p}=0,003)$. A restrição dietética do leite naqueles pacientes com DETD e TCA positivo foi associada à melhora clínica em $80 \%$ dos pacientes e associação com melhora histológica em $65 \%$ destes. Conclusões: O TCA utilizando tanto LV in natura como extrato LV a $20 \%$, com leitura após 48 ou $72 \mathrm{hs}$ da sua aplicação mostrou-se útil na identificação de pacientes com DETD desencadeada pelo LV. A instituição de dieta restrita neste alimento contribuiu para a melhora dos sintomas e para a redução do número de eosinófilos na biópsia de controle.

Descritores: hipersensibilidade alimentar, esofagite eosinofilica, enterite, leite de vaca, diagnóstico, testes cutâneos, crianças, adolescentes 


\section{SUMMARY}

Frayha-Souza FR .Evaluation of atopic patch test (APT) in IgE mediated cow's milk allergic patients and those with gastrointestinal eosinophilic diseases (Dissertation). São Paulo: Faculdade de Medicina da Universidade de São Paulo;2011.

Objective: To evaluate the atopic patch test (APT) in IgE mediated cow's milk allergic patients (CMA) - Group 1 and those with gastrointestinal eosinophilic diseases (GED) - Group 2, comparing extracts of cow's milk (CM) $20 \%$ protein concentration and fresh milk, the optimal time reading and the positive predictive value of APT in the identification of milk as a trigger food in the group 2, as assessed by clinical and endoscopic improvement after dietary restriction. Methods: Cross-sectional study with evaluation of 45 patients and 9 controls. The group $1(n=15)$ with IgE-mediated CMA was diagnosed by provocation test and positive skin prick test for $\mathrm{CM}$ in all patients and group $2(n=30)$ by biopsy showing eosinophilic esophagitis ( $\geq$ 15 eosinophils / hpf) or eosinophilic enterocolitis (> 20 eosinophils / hpf ), prick test positive for CM $(n=15)$ and symptoms triggered by milk. Group 3 $(\mathrm{n}=9$ ) included patients which CMA was excluded. It was used $12 \mathrm{~mm}$ a plastic chamber of inert material, and as extracts the fresh milk and CM at 20\% (IPI ASAC, Spain). The reading times were 24, 48 and 72 hours and was considered as APT positive, the presence of hyperemia with infiltration and papules or vesicles. To evaluate the positive predictive value of the APT, it was considered GED patients with symptoms associated to milk, no response to treatment, specific $\operatorname{lgE}$ to $\mathrm{CM}$ and clinical and histological improvement after the restricted diet institution. Results: Considering both extract, there was similarity in the frequency of positive APT evaluating all the reading times in both clinical situations. Regarding the agreement between the reading times with both extracts, there was a statistically significant difference between the time of 24 hours with those of 48 and 72 hours ( $p=$ 0.031 for both comparisons). This fact was not observed between the time of 
48 and 72 hours in both diseases. The CM 20\% extract showed a similar pattern in both diseases, with difference between the reading time of 24 with the 48 hours $(p=0.031 / 0.000)$ and 72 hours $(p=0.031 / 0.002)$ respectively in both diseases. The fresh milk extract in CMA patients showed no statistically significant difference between the reading times evaluated, while in GED patients it was observed difference between 24 hours with the time of 48 hours $(p=0.003)$ and 72 hours $(p=0.003)$. The milk restricted diet for GED patients with positive APT was associated to clinical improvement in $80 \%$ of patients and in both clinical and histological response in $65 \%$ of them. Conclusions: The APT using both fresh CM and CM 20\% extract with reading time of 48 or 72 hours showed useful in identifying GED patients triggered by $\mathrm{CM}$. The establishment of milk restricted diet contributed to the improvement of symptoms and to reduce the number of eosinophils in the control biopsy.

Keywords: food hypersensitivity, eosinophilic esophagitis, enteritis, cow's milk, diagnosis, skin tests, children, adolescents 
Introdução 


\section{INTRODUÇÃO}

\subsection{ALERGIA ALIMENTAR}

Reações adversas aos alimentos (RAA) é a denominação empregada para qualquer reação anormal que ocorra após a ingestão de alimentos. Anteriormente, essas reações eram classificadas em tóxicas e não tóxicas (Sampson, 1999). Em 2010, o National Institute of Allergy and Infectious Diseases (USA), trabalhando com 34 organizações profissionais, agências federais, e grupos de defesa do paciente liderou o desenvolvimento de diretrizes clínicas para o diagnóstico e tratamento da alergia alimentar. Este consenso definiu Alergia Alimentar (AA) como uma reação a um determinado alimento, mediada pelo sistema imunológico, que pode ser mediada pela imunoglobulina E (IgE mediada), não IgE mediada ou mista. Além disso, estabeleceu orientações para serem utilizadas por uma grande variedade de profissionais de saúde, incluindo médicos de família, clínicos e profissionais de enfermagem. As diretrizes apresentam 43 recomendações clínicas concisas e orientações adicionais sobre as controvérsias atuais no manejo do paciente. Os autores também tiveram como proposta, identificar lacunas no conhecimento científico atual, que poderão ser abordadas através de pesquisas futuras (Boyce et al, 2010).

Nas últimas décadas tem sido constatado um aumento da prevalência das doenças alérgicas, incluindo as alergias alimentares, sendo este fato atribuído a mudanças no estilo de vida da população e também a novos hábitos alimentares. As alergias alimentares tornaram-se um grande problema de saúde e estão associadas a um impacto negativo significativo na qualidade de vida dos indivíduos (Sicherer e Sampson, 2006). Estima-se que a prevalência da AA seja de 6-8\% em crianças menores de 3 anos e cerca de 2-4\% em adultos (Sampson, 2004; Nowak-Wegrzyn e Sampson, 2006). 
Os fatores de risco associados à maior prevalência de $A A$ são: história familiar de atopia entre parentes de primeiro grau, presença de dermatite atópica e agravos do trato gastrintestinal (Wahn \& Von Mutius, 2001; Garside et al, 2004). Aproximadamente 35 a 40\% das crianças com dermatite atópica moderadas e graves têm associação com AA (NowakWegrzyn e Sampson, 2006). Entre os adultos com dermatite atópica esta associação é pouco comum, atingindo cerca de $2 \%$ dos pacientes (Burks et al,1998; Niggemann et al,1999; Rancé, 2008). Desta maneira, pacientes pediátricos com dermatite atópica moderada ou grave constituem um dos grupos que apresenta maior prevalência de $A A$, sendo as proteínas do leite de vaca e do ovo os principais alérgenos alimentares envolvidos (Werfel et al, 2007).

Vários estudos prospectivos de crianças com alergia ao leite de vaca realizados nas décadas de 1980 e 1990 mostraram que grande parte dos pacientes desenvolvia tolerância a este alimento aos três anos de idade (Host et al, 2002). Entretanto, ao longo dos anos, observou-se a persistência da alergia às proteínas do leite de vaca (APLV), com o desenvolvimento de tolerância em escolares ou mesmo adolescentes, modificando o conceito anteriormente descrito, do desenvolvimento da tolerância na primeira infância (Skripak, 2007).

Em relação à fisiopatogênese da alergia alimentar, vários fatores têm papel importante, dentre eles a genética, a flora intestinal do hospedeiro, a dosagem e a frequência de exposição a vários alérgenos alimentares, bem como a alergenicidade das várias proteínas alimentares (Sicherer et al, 2000)

Atualmente, fatores epigenéticos também têm sido valorizados. O tipo de alimentação, as formas de contato com os microorganismos, época de administração de alérgenos alimentares e padrão de permeabilidade da mucosa intestinal influenciam a regulação do sistema imunológico levando a diferentes padrões de resposta imunológica ao alimento. Entre as características genéticas, o polimorfismo dos genes associados à resposta imunológica e a falha na atividade de células T regulatórias (Treg) têm maior 
destaque nas pesquisas envolvendo alergias alimentares (Sampson et al, 1999 e Prescot et al, 2010).

A produção de anticorpos IgE alérgeno-específicos possui um papel importante nas reações de hipersensibilidade imediata tipo I. Em outras formas de hipersensibilidade alimentar, tal como a enterocolite induzida por proteínas, mecanismos imunes não lgE-mediados parecem ser predominantes. Há evidências de que as doenças eosinofílicas do trato digestório podem ser causadas pela resposta anormal das citocinas Th2 (IL4, IL5) e pela produção da eotaxina 3 , resultando na ativação e recrutamento de eosinófilos (Hogan et al, 2004; Spergel, 2007).

Embora haja uma grande ingestão de alimentos com elevada carga antigênica, cerca de $90 \%$ das manifestações de alergia alimentar estão relacionadas a um grupo pequeno de alimentos destacando-se o leite, o ovo, a soja, o trigo, o amendoim, os crustáceos e as castanhas (Sicherer e Sampson, 2006). Entre estes, o leite de vaca é o mais freqüente e o primeiro alimento oferecido à criança após o desmame.

O diagnóstico adequado é ponto crucial em AA, para evitar exclusões dietéticas desnecessárias do alimento, que podem resultar em deficiências nutricionais, com conseqüente interferência na qualidade de vida dos pacientes e seus familiares. Pacientes com alergias IgE- mediadas podem se beneficiar da pesquisa da IgE específica através dos testes de hipersensibilidade imediata (prick teste) ou Immunocap®, mas algumas vezes é necessária a realização dos testes de provocação, especialmente o teste de provocação oral duplo cego placebo controlado (TPODCPC), ainda considerado padrão ouro para o diagnóstico de AA (Williams e Bock, 1999). Entretanto, este teste demanda estrutura adequada e profissionais treinados, não sendo isento de riscos (Niggemann e Beyer, 2007).

Os pacientes que apresentam sinais ou sintomas típicos de reações mistas ou não IgE-mediada, geralmente são diagnosticados pela resposta à eliminação do alérgeno da dieta e algumas doenças necessitam de avaliação anatomopatológica. Nestes casos, outro teste diagnóstico denominado Teste de Contato com Alimentos pode ser útil, visto que o 
mecanismo celular está envolvido. A associação do teste de contato com o teste de puntura pode aumentar significativamente a acurácia diagnóstica da alergia alimentar em pacientes com sintomas gastrintestinais ou com dermatite atópica (Isolauri et al,1996).

\subsection{ALERGIA ÀS PROTEÍNAS DO LEITE DE VACA}

O leite de vaca contêm aproximadamente 30 a $35 \mathrm{~g} / \mathrm{L}$ de proteínas, sendo as mais relacionadas à alergia alimentar: a $\beta$-lactoglobulina, caseína e a a-lactoalbumina. Estas proteínas preenchem as características necessárias para um bom alérgeno por apresentarem propriedades físicoquímicas adequadas: peso molecular entre 10 e 70 kDa e são glicoproteínas hidrossolúveis, sendo algumas delas termoestáveis e resistentes ao processamento digestivo. Estudos em grandes populações de indivíduos alérgicos a esse alimento têm mostrado que a maioria dos pacientes são sensibilizados a mais de uma proteína. A proteína $\beta$ - lactoglobulina ocorre naturalmente na forma de um dímero de 36 kDa e não está presente no leite materno. Como característica, é bastante resistente à hidrólise ácida e à ação de proteases, permitindo que parte desta proteína seja absorvida no trato gastrintestinal na forma intacta (Wal, 2004). A a- lactoalbumina bovina é uma proteína de 14,4 kDa e apresenta homologia com a a- lactoalbumina humana. A caseína é o principal constituinte do coágulo do leite, apresentando várias isoformas, como as-1, as-2 e k- caseína (Wal, 2004). Caracteriza-se pela alta resistência a processamento térmico, embora seja sensível à ação de proteases. É importante salientar, que mesmo seus fragmentos resultantes da ação proteolítica podem conservar parte da alergenicidade da proteína nativa (Chatchatee et al,2001). 


\subsection{MANIFESTAÇÕES CLÍNICAS DA ALERGIA ÀS PROTEINAS DO LEITE DE VACA}

\subsubsection{Manifestações Clínicas IgE mediadas}

Nas manifestações clínicas da APLV IgE mediada, os sintomas aparecem até duas horas após a ingestão do leite. Após a sensibilização com formação de IgE específica, esse anticorpo circula pelo organismo e liga-se a receptores de alta afinidade em mastócitos e basófilos. Nos próximos contatos com o alérgeno, a ligação deste à IgE, que se ligou aos mastócitos e basófilos, promoverá a liberação de mediadores tais como histamina, prostaglandinas e leucotrienos, que são responsáveis pelas manifestações clínicas (Fiocchi et al, 2010).

As manifestações cutâneas $\mathrm{e}$ as gastrintestinais são as mais freqüentes. As manifestações cutâneas incluem: urticária, urticária de contato, angioedema e eritema.

As manifestações gastrintestinais incluem: síndrome da alergia oral (SAO), dor abdominal, náuseas, diarréia e vômitos. A síndrome da alergia oral se manifesta mais comumente no adulto, principalmente após a ingestão de legumes e frutas não processadas, mas também pode acometer pacientes pediátricos (Fiocchi et al, 2010).

A asma e a rinite raramente ocorrem como manifestação isolada após a ingestão de leite, mas são importantes, pois estão associadas com manifestações graves (James J, 2003). Crianças com asma desencadeada por alimentos são um fator de risco para anafilaxia (Bahna SL, 2001). Após TPODCPC em crianças com APLV, $70 \%$ delas apresentaram manifestações de rinite e $8 \%$ de asma (James J, 2003).

A manifestação mais grave da APLV IgE mediada é a anafilaxia, com sintomas clínicos variados. Classicamente, o comprometimento cutâneo está presente em $70-80 \%$ dos casos caracterizado por prurido, vermelhidão na pele, urticária e angioedema, na maior parte dos casos. Vômitos, diarréia, 
cólica abdominal, dificuldade respiratória, hipotensão, síncope e choque também são descritos como sintomas clássicos (Wang et al, 2007).

\subsubsection{Manifestações Clínicas Não IgE Mediada}

As reações podem ocorrer horas a dias após a ingestão do alimento, acometendo principalmente o trato gastrintestinal.

$\mathrm{Na}$ proctocolite alérgica, as manifestações têm início entre a segunda e a oitava semana de vida, sendo característicos os sangramentos intestinais e a manutenção de bom estado geral. Mais de $50 \%$ dos pacientes relatados estavam em aleitamento materno (Lake et al,1982). A instituição de dieta de eliminação do leite é acompanhada de melhora dos sintomas em 72 a 96 horas.

$\mathrm{Na}$ enteropatia induzida por proteínas do leite de vaca, as manifestações clínicas são decorrentes do comprometimento do intestino delgado, com estabelecimento gradual dos sintomas, incluindo diarréia protraída, anorexia, baixo ganho ponderoestatural, vômitos e eventualmente edema em consequência da hipoproteinemia. A anemia pode ser encontrada em $60 \%$ destes pacientes, ocorrendo geralmente em lactentes (Solé D et al, 2008).

A enterocolite induzida por proteínas do leite de vaca inicia-se nos primeiros meses de vida é decorrente do comprometimento intestinal. Inclui baixo ganho ponderoestatural, vômitos, diarréia com ou sem sangue, desidratação e $20 \%$ dos casos podem evoluir com choque (Nowak-Wegrzyn e Sampson HA, 2006).

\subsubsection{Manifestações Mistas}

Neste tipo de reações ocorre o envolvimento dos mecanismos $\lg E$ mediado, além da participação de linfócitos $T$ e eosinófilos. Vários órgãos podem ser acometidos, tais como o esôfago, o estômago e porções do intestino delgado e grosso. A dermatite atópica e a asma também podem ser manifestações deste tipo de mecanismo fisiopatológico. 


\subsubsection{Esofagite Eosinofílica}

A esofagite eosinofílica (EoE) é uma doença crônica do esôfago, imunomediada, caracterizada por disfunção esofagiana e histopatologicamente definida por uma infiltração eosinofílica do esôfago com pelo menos 15 eosinófilos/cga (Liacouras et al, 2011). Essa doença acomete preferencialmente o sexo masculino e apresenta sintomas semelhantes à doença de refluxo gastroesofágico (náuseas, vômitos, regurgitação, dor epigástrica, e dificuldades à alimentação), mas com má resposta ao tratamento desta doença. Outros achados clínicos são: recusa alimentar em lactentes e pré escolares e impactação e lou disfagia em adolescentes (Nowak-Wegrzyn e Sampson , 2006; Furuta et al, 2007). Aproximadamente $42 \%$ a $93 \%$ dos pacientes pediatricos têm história pessoal de asma, rinite, eczema, AA e em $50 \%$ a $60 \%$ dos casos a história familiar de atopia está presente (Prasad et al, 2009).

$\mathrm{Na}$ EoE a alteração fisiopatológica encontrada é um aumento na infiltração de linfócitos TH2, e um aumento na expressão de citocinas, em especial a IL- 5 e da eotaxina 3 (Furuta et al, 2007).

A prevalência da EoE vem aumentando progressivamente, tanto pelo maior conhecimento da doença, quanto pelo aumento absoluto no número de casos, como observado em diversos países (Spergel, 2007). A taxa de incidência é de 1,25/10000 e prevalência de 4,3/10000 em crianças menores de 19 anos (Noel et al, 2004).

Na EoE há uma associação com a hipersensibilidade a múltiplos alimentos, principalmente nas crianças. Em crianças maiores e adultos, os aeroalérgenos são mais implicados (Fiocchi et al, 2010). O diagnóstico da EoE é realizado através de endoscopia com biópsia esofágica evidenciando $\geq 15$ eosinófilos/cga. Os achados endoscópicos macroscópicos são anéis concêntricos (traqueização), placas esbranquiçadas, linhas longitudinais e edema (Furuta et al, 2007). Recomenda-se pelo menos 2 a 4 sítios de biópsias do esôfago proximal e distal (Liacouras et al, 2011). A presença de 5 sítios aumenta a acurácia diagnóstica em $90 \%$ dos casos (Gonsalves et al, 2006). 
Aproximadamente $10 \%$ dos adultos com disfagia e endoscopia normal apresentam alteração histológica compatível com EoE (Yan BM e Shaffer $E A, 2009)$.

A associação entre alergia alimentar e EoE vem sendo estudada por meio da correlação entre os alimentos clinicamente implicados com os sintomas e através da avaliação do prick teste e TCA (Spergel, 2007). Hipersensibilidade imediata a alimentos em pacientes com EoE varia de $15 \%$ a $43 \%$ (Prasad et al, 2009).

Dietas elementares têm demonstrado resolução dos sintomas e normalização da biópsia em aproximadamente 95\% dos casos (Liacouras et al, 2005). Entretanto, devido à baixa palatabilidade destas fórmulas elementares, a dieta de eliminação feita após a realização de prick teste e TCA tem sido preferida com uma taxa de resolução de $75 \%$ (Spergel et al, 2002).

\subsubsection{Gastroenterite Eosinofílica}

A gastroenterite eosinofílica é uma doença, cuja histopatologia é caracterizada por aumento de eosinófilos nas camadas mucosa, muscular e serosa do estômago e intestino e, menos frequentemente no cólon. Seu mecanismo fisiopatológico ainda não está totalmente esclarecido e até o momento é considerada uma doença rara, podendo afetar qualquer idade, com pico de incidência entre 30-50 anos, acometendo principalmente o sexo masculino (Yan BM e Shaffer EA, 2009). Essa doença caracteriza-se por sintomas inespecíficos como diarréia, dor abdominal, perda de peso e vômitos. Em quadros mais graves pode ocorrer sangramento intestinal, anemia ferropriva, enteropatia perdedora de proteína e edema generalizado. A eosinofilia periférica pode estar presente em $50 \%$ dos pacientes, e a atopia está associada em 25-75\% dos casos (Khan S e Orenstein SR, 2002).

O diagnóstico é feito através de endoscopia e colonoscopia que frequentemente mostram lesões inespecíficas como eritema, lesões friáveis, nodulares e ulceradas. A biópsia apresenta número aumentado de 
eosinófilos em uma ou mais áreas do trato gastrintestinal do esôfago ao cólon (Powell et al, 2010), sendo considerado como método diagnóstico a contagem $\geq 20$ eosinófilos por cga, após exclusão de outras doenças que também são acompanhadas de infiltração eosinofílica como parasitoses , reações adversas a drogas e doenças mieloproliferativas (Talley et al, 1990).

\subsection{DIAGNÓSTICO DA ALERGIA ÀS PROTEINAS DO LEITE DE VACA}

\subsubsection{Anamnese}

O diagnóstico de APLV envolve uma anamnese minuciosa. Os dados obtidos podem sugerir o alimento desencadeante, bem como o mecanismo fisiopatológico envolvido, direcionando a investigação laboratorial para a confirmação diagnóstica. Devem ser abordados os seguintes aspectos: idade do início dos sintomas, intervalo de tempo entre a ingestão do alimento suspeito e o início dos sintomas, descrição dos sinais e sintomas apresentados, necessidade de atendimento em pronto socorro, tratamento utilizado e evolução clinica. Em relação ao provável alimento desencadeante devem ser avaliados: quantidade do alimento desencadeante, processamento e a reprodutibilidade do sintoma após a nova ingestão do alimento (Fiocchi et al ,2010).

\subsubsection{Exames complementares}

Os exames laboratoriais que auxiliam na detecção do alimento ou dos alimentos envolvidos na gênese dos sintomas são: a pesquisa da $\lg E$ especifica in vivo através do prick teste (Pepys,1975) e in vitro através do ImmunoCAP (Nowak-Wegrzyn e Sampson, 2006 ; Eigenmann et al, 2011). Além destes, os testes de provocação podem ser indicados, sendo o TPODCPC considerado o padrão ouro para o diagnóstico. 


\subsubsection{Prick teste}

A resposta é baseada na reação de hipersensibilidade do tipo I na qual, pela presença de lgE específica contra o alimento testado, ocorre a degranulação de mastócitos e liberação de histamina tendo como expressão clínica, a formação de uma pápula no local do teste. Este teste apresenta baixo valor preditivo positivo (<50\%), podendo ser positivos em pacientes sem história clínica de alergia alimentar, indicando apenas sensibilização (Sampson, 2003).

Hill et al (2001), avaliando crianças com alergia alimentar, propuseram determinados valores de pápulas acima das quais os pacientes têm grande chance $(95 \%$ a $100 \%)$ de apresentarem um teste de provocação oral duplo cego placebo controlado positivo (TPODCPC). Os autores relataram que crianças menores de 2 anos de idade com diâmetro da pápula maior ou igual a $6 \mathrm{~mm}$ para leite de vaca, podem ser dispensadas do TPODCPC, já que esses valores estão associados a um valor preditivo positivo maior que 95\%. Em crianças acima de 2 anos com APLV e diâmetro da pápula maior ou igual a $8 \mathrm{~mm}$, apresenta interpretação semelhante.

A realização do teste pode ser feita com extratos comerciais do leite de vaca e suas frações ou aplicando-se o próprio alimento in natura, em uma técnica conhecida como prick to prick (Rancé et al,1997).

Pacientes com diagnóstico de dermatite atópica, dermografismo e em uso de medicações como anti-histamínicos, corticóides orais e tópicos por tempo prolongado podem alterar a resposta cutânea e influenciar os resultados do exame (Hamilton, 2003).

\subsubsection{Pesquisa de IgE sérica específica in vitro}

Diferentes métodos podem ser utilizados para detecção de $\lg E$ específica in vitro, sendo o sistema ImmunoCAP ${ }^{\circledR}\left(\right.$ UniCAP $^{\circledR}$ System, Pharmacia Diagnostics AB, Uppsala, Suécia) o ensaio mais sensível e reprodutível (Wide et al,1967). Apesar deste ensaio ser uma modificação do radioimunoensaio original e não mais utilizar radioisótopos, o termo RAST 
ainda é empregado na prática clínica. Descrito por Wide et al (1967), o RAST $^{\circledR}$ (Radio Allergo Sorbent Test, Pharmacia Diagnostics AB, Uppsala, Suécia) foi um dos primeiros métodos utilizados para a quantificação dos anticorpos $\lg E$ específicos no soro de pacientes alérgicos. $O$ alérgeno era covalentemente ligado à fase sólida e incubado com o soro do paciente. Após um período de incubação, os anticorpos IgE específicos se ligavam à fase sólida. Esta era lavada extensivamente e colocada em contato com anticorpos anti-IgE marcados radioativamente. A contagem da anti-lgE marcada refletia a quantidade de IgE específica ligada ao alérgeno. Os resultados eram exibidos de maneira semi quantitativa em classes que variavam de 0 a 6 (Hamilton, 2003). Esta técnica foi modificada nos últimos anos, sofrendo evolução tecnológica do método que ainda mantém os mesmos princípios, mas os resultados podem ser avaliados de maneira quantitativa (Ahlstedt et al, 2002). Este teste pode ser realizado em pacientes que apresentam anafilaxia, dermatite atópica ou que estejam utilizando antihistamínicos, corticóides tópicos ou orais. Apresenta elevado valor preditivo negativo, mas se positivo ,assim como prick teste, indica apenas sensibilização (Vandenplas et al, 2007).

A modernização da metodologia de dosagem de IgE sérica específica e o consequente aumento da sensibilidade com a introdução do método ImmunoCAP ${ }^{\circledR}$ tem possibilitado a correlação entre os níveis séricos de lgE específica e reatividade clínica.

\subsubsection{Testes de provocação oral}

Podem ser realizados de três maneiras: provocação aberta, simples cego e teste provocação oral duplo cego placebo controlado (TPODCPC).

Nas últimas décadas, O TPODCPC tem sido considerado o "padrão ouro" para o diagnóstico de alergia alimentar em diversos estudos (Bock et al, 1987; William e Bock, 1999; Niggeman e Beyer, 2007), pois apresenta qualidades que permitem com que seja usado como referência na determinação de um novo método diagnóstico. Neste tipo de teste, tanto o 
médico como o paciente desconhecem o alimento ingerido pelo paciente, sendo necessária uma fase placebo. Este teste é considerado padrão ouro para o diagnóstico de alergia alimentar. Para sua realização é necessária equipe treinada, pois não se trata de teste isento de riscos, devendo ser realizado sempre em ambiente hospitalar ou com condições de atendimento de urgência. O TPODCPC apresenta como principal característica a possibilidade de reproduzir os sintomas desencadeados em uma exposição natural sem que pacientes, familiares ou mesmo equipe médica possam influenciar nos resultados, reduzindo com isto a possibilidade de resultados falso positivos. Através deste teste, pode-se estimar a dose de alimento necessária para induzir os sintomas e determinar a aquisição de tolerância (Williams e Bock, 1999).

Embora este teste seja considerado "padrão ouro", há uma série de desvantagens associadas ao TPODCPC destacando-se o tempo necessário para sua realização, os custos envolvidos, estrutura física e a necessidade de mobilização de pessoal treinado na análise de resultados e possíveis eventos adversos.

\subsubsection{Teste de contato atópico com alimentos}

O teste de contato atópico, atualmente está sendo utilizado como ferramenta no diagnóstico da AA, em especial nas manifestações mistas e não lgE mediadas. A primeira descrição do TCA foi feita por Michell et al em 1982, em pacientes com dermatite atópica, quando os autores verificaram que a aplicação epicutânea de alérgenos na pele não lesionada levava à lesão eczematosa. Neste estudo o uso do TCA nos pacientes com dermatite atópica mostrou-se eficaz, principalmente para demonstrar a sensibilização a alérgenos respiratórios (Mitchell et al, 1982).

O primeiro artigo publicado por Breneman et al, em 1989 relacionando TCA com alimentos foi realizado em mais de 400 pacientes. Neste estudo, foi utilizado um teste comercial com alérgenos em suspensão de dimetilsulfoxido, já descontinuado. Não houve comparação com provocação oral, 
mas foi importante para demonstrar a segurança do teste (Breneman et al, 1989).

A primeira descrição controlada realizada com alimentos no TCA foi publicada em 1996, por Isolauri e Turjanmaa, utilizando a associação entre prick teste e TCA para o diagnóstico de alergia ao leite em pacientes com dermatite atópica, comparados ao teste de provocação oral para o leite de vaca, com o objetivo de reduzir a restrição dietética empírica realizada naqueles pacientes. Nesse estudo, os autores demonstraram correlação entre prick teste e reações imediatas no teste de provocação em $67 \%$ das vezes e correlação positiva entre os sintomas tardios da provocação oral e a positividade dos TCA em 89\% (Isolauri e Turjanmaa, 1996).

Em 2006, a European Academy of Allergy and Clinical Immunology (EAACl) publicou um artigo se posicionando com relação ao TCA, tanto para aeroalérgenos quanto para alimentos (Turjanmaa et al, 2006). Essa revisão concluiu que para os pacientes com dermatite atópica, a associação entre o prick teste, IgE sérica específica para alimentos e o TCA auxiliavam no diagnóstico. Neste mesmo artigo, a recomendação é que, enquanto não houver uma padronização de extratos, se utilizem os alimentos in natura.

A primeira publicação do TCA nos pacientes com EoE foi em 2002. Os autores utilizaram a associação dos prick teste e TCA com alimentos na tentativa de elucidação dos prováveis alérgenos envolvidos na EoE (Spergel et al, 2002). Em 2006, foi descrita a utilização do TCA para alimentos em pacientes com síndrome da enterocolite induzida pela proteína do alimento, que apresenta mecanismo não lgE-mediado (Fogg et al, 2006).

Há uma série de estudos tentando avaliar o impacto deste exame no diagnóstico da alergia alimentar, tanto em manifestações com mecanismos mistos, quanto em quadros não IgE mediados, em uma tentativa de evitar que o paciente se submeta aos testes de provocação oral. Inicialmente estudos eram realizados em pacientes com dermatite atópica e, mais recentemente, em pacientes com esofagite eosinofílica (Spergel et al ,2002 ; Darsow et al, 2004, Niggemann et al, 2000) 


\subsection{Técnica para a realização do TCA}

O TCA é uma variação do teste de contato utilizado no diagnóstico de dermatite de contato, entretanto diferem na natureza do alérgeno. O teste para dermatite de contato utiliza haptenos, enquanto no TCA aplicam-se na pele os alérgenos proteicos, que produzem inicialmente uma reação de hipersensibilidade tipo I evoluindo para uma lesão eczematosa depois de 48 a 72 horas (Darsow et al,1999; Ring et al, 1989). Alguns estudos relataram que uma reação precoce do TCA representa uma resposta imunológica do tipo Th2, enquanto que na fase tardia a resposta imunológica é tipo Th1 (Thepen et al, 1996). Na literatura existe um estudo que sugere a hipótese de que a IgE também possa estar envolvida em reações tardias do TCA (Holm et al, 2004).

Em relação ao tipo de câmara utilizada no teste, a maioria dos estudos utilizaram as câmaras de alumínio (Finn Chamber), que podem ser de $6 \mathrm{~mm}$, $8 \mathrm{~mm}$ ou $12 \mathrm{~mm}$. A acurácia do diagnóstico foi maior utilizando as câmaras de $12 \mathrm{~mm}$, comparadas com as de $6 \mathrm{~mm}$ (Niggemann et al, 2002). As câmaras são colocadas no dorso do paciente e removidas após 48 horas. Depois da remoção, a primeira leitura é feita 20 minutos após a retirada da câmara e uma leitura final após 72 horas (Niggemann B, 2002; Keskin et al, 2005; Majamaa et al, 1999; Isolauri \& Turjanmaa, 1996).

Embora pareça bastante promissor, o TCA ainda necessita de padronização quanto ao tipo, quantidade do alérgeno e veículo utilizado. Recentemente, pesquisadores concluíram que a vaselina parece ser o veículo ideal e que as câmaras de Finn Chamber de $12 \mathrm{~mm}$ seriam as mais adequadas para utilização (Niggemann et al, 2002; Turjanmaa et al, 2006). Entre as dificuldades encontradas para a sua realização, destacam-se a concentração ideal do alérgeno e qual alérgeno entre vários de um mesmo alimento deve ser utilizado. Assim, ainda há necessidade de padronização em relação a todos estes fatores. Em nosso meio não existe nenhum estudo que aborda este aspecto. O quadro 1 resume os principais estudos com 0 TCA descritos na literatura e os diferentes tempos de oclusão e alérgenos empregados. 
Quadro 1. Características das diversas metodologias empregadas no TCA em alergia alimentar, nos diversos estudos publicados.

\begin{tabular}{|c|c|c|c|c|c|}
\hline Autores & $\begin{array}{c}\text { Tempo de } \\
\text { leitura em } \\
\text { horas }\end{array}$ & $\begin{array}{c}\text { Tamanho } \\
\text { Finn } \\
\text { Chamber }\end{array}$ & $\begin{array}{c}\text { Material } \\
\text { da Finn } \\
\text { Chamber }\end{array}$ & Alérgeno & Controle \\
Rancé, 2004 & $24,48,72$ & $12 \mathrm{~mm}$ & Alumínio & $\begin{array}{c}\text { Leite de vaca, ovo, } \\
\text { amendoim, trigo } \\
\text { (mesmo extrato do } \\
\text { prick teste) }\end{array}$ & Vaselina \\
\hline $\begin{array}{c}\text { Ronchetti et } \\
\text { al, 2008 }\end{array}$ & 48,72 & $10 \mathrm{~mm}$ & Plástico & $\begin{array}{c}\text { Leite de vaca, ovo, } \\
\text { tomate, trigo, } \\
\text { aeroalérgenos (Dp) } \\
\text { ALK-ABELLO }\end{array}$ & $\begin{array}{c}\text { Solução } \\
\text { salina }\end{array}$ \\
\hline $\begin{array}{c}\text { Canani et al, } \\
2007\end{array}$ & 48,72 & $12 \mathrm{~mm}$ & Alumínio & $\begin{array}{c}\text { Leite de vaca in } \\
\text { natura e extrato de } \\
\text { leite de vaca a 20\% }\end{array}$ & $\begin{array}{c}\text { Solução } \\
\text { salina }\end{array}$ \\
\hline $\begin{array}{c}\text { Isolauri e } \\
\text { Turjanmaa, } \\
1996\end{array}$ & 48,72 & Não cita & Alumínio & $\begin{array}{c}\text { Leite de vaca } \\
\text { desnatado }\end{array}$ & $\begin{array}{c}\text { Celulose } \\
\text { microcristali } \\
\text { na }\end{array}$ \\
\hline $\begin{array}{c}\text { Darsow et al, } \\
2004\end{array}$ & $24,48,72$ & $12 \mathrm{~mm}$ & Alumínio & $\begin{array}{c}\text { Aeroalérgenos, } \\
\text { ovo, trigo, Aipo }\end{array}$ & Vaselina \\
\hline $\begin{array}{c}\text { Niggemann } \\
\text { et al, 2000 }\end{array}$ & 48,72 & $12 \mathrm{~mm}$ & Alumínio & $\begin{array}{c}\text { Leite de vaca, ovo } \\
\text { trigo e soja } \\
\text { (alimentos in } \\
\text { natura) }\end{array}$ & Não cita \\
\hline
\end{tabular}

\subsection{Interpretação do TCA para alimentos}

A European Task Force on Atopic Dermatitis em 2003 apresentou uma revisão da interpretação dos TCA para alimentos na dermatite atópica.

Quadro 2 . Proposta para leitura do TCA segundo European Task Force on Atopic Dermatitis, 2003

\begin{tabular}{|c|c|c|}
\hline \multicolumn{2}{|c|}{ LEITURA } & RESULTADO \\
\hline- & Negativo & Negativo \\
\hline$?$ & Somente eritema & Duvidoso \\
\hline+ & Eritema, infiltração & Positivo \\
\hline++ & Eritema, algumas pápulas & Positivo \\
\hline+++ & Eritema, várias pápulas & Positivo \\
\hline++++ & Eritema, vesículas & Positivo \\
\hline
\end{tabular}


Quanto à leitura do TCA, um recente estudo propôs uma padronização na interpretação do teste em crianças com dermatite atópica e suspeita de AA e observaram que a presença de infiltração além dos limites da câmara da Finn Chamber e a presença de pelo menos sete pápulas na leitura às 72 horas têm grande acurácia diagnóstica, correlacionando-se com TPODCPC (Heine et al, 2006).

Os ensaios clínicos com TCA realizados, desde o artigo de Isolauri e Turjanmaa, são heterogêneos quanto à seleção da população estudada manifestações clínicas e idade sendo que somente uma minoria incluiu controles saudáveis (Ronchetti et al, 2008).

\subsection{A aplicação do TCA na Esofagite Eosinofilica}

Estudos realizados em pacientes com esofagite eosinofílica, demonstraram que a associação dos TCA e o prick teste ou IgE sérica específicas para alimentos aumenta a probabilidade de diagnóstico nestes pacientes. Isto poderá reduzir o uso de dietas hidrolisadas ou elementares, reduzindo o custo e melhorando a qualidade de vida dos pacientes (Spergel et al, 2002).

Evidências que suportam a alergia a alimentos como um dos desencadeantes da EoE são baseadas na associação de sintomas com a ingestão de alimentos específicos, sendo que vários trabalhos demonstram que crianças tratadas com fórmula elementar melhoram da EoE (Liacouras, 2003). Devido à baixa palatabilidade e ao alto custo da fórmula elementar, estes mesmos autores desenvolveram um estudo com dietas de eliminação baseadas no prick teste e no TCA. Em média, os pacientes eram alérgicos a 5 alimentos e após a eliminação destes, houve melhora dos sintomas. Os pesquisadores afirmam que há dificuldade em identificar alérgenos individualmente, pois o padrão-ouro para o diagnóstico corresponde à biópsia pré e pós reintrodução de um único alimento. Devido a este fato, aconselham aliar os resultados do prick teste e TCA para o diagnóstico do alimento desencadente da EoE. (Turjanmaa et al, 2006). Assim, o TCA utilizado em associação com a dosagem de lgE sérica específica ou com 
prick teste, pode auxiliar no diagnóstico e tratamento dos pacientes com alergia alimentar de mecanismo misto e possivelmente, naquelas mediadas exclusivamente por células (Vanto et al,1999; Sicherer et al, 2000). Há a necessidade de mais estudos para verificar quais seriam as formulações mais adequadas para a realização dos TCA, se in natura ou extratos protéicos.

A utilidade desse teste tem embasamento crescente na literatura e inclusive a posição da EAACl é favorável a sua realização nessas patologias e em casos específicos (Darsow et al, 2004).

A Unidade de Alergia e Imunologia tem desde 2003, um ambulatório de AA e após a padronização do TPODCPC decidiu avaliar a real contribuição do TCA em pacientes com EoE e também nas AA IgE mediadas, já que os estudos têm mostrado que em leituras precoces do TCA a IgE está envolvida na patogênese desta reação (Darsow et al, 2004; Heinemann et al, 2002). Este fato tem sido observado com a aplicação de aeroalérgenos no TCA, principalmente o Dermatophagoides pteronyssinus (Dp) em pacientes com Asma e Rinite (Seidenari et al, 1992; Guler, 2006). Isto também poderia nos auxiliar a definir quais pacientes com EoE necessitam de restrição dietética para melhora da sintomatologia associada à EoE. Como não havia definição da padronização do teste em nosso meio, este aspecto também foi contemplado neste estudo. 
Objetivos 


\section{OBJETIVOS}

\subsection{PRINCIPAL}

Avaliação do teste de contato atópico em pacientes com alergia às proteínas do leite de vaca IgE mediada e naqueles com doenças eosinofílicas do trato digestório.

\subsection{SECUNDÁRIOS}

2.2.1. Comparar a freqüência de positividade do TCA quando utilizado o extrato de leite de vaca a $20 \%$ e o leite in natura nos pacientes com APLV $\lg$ E medida e nas doenças eosinofílicas do trato digestório

2.2.2. Comparar a positividade do TCA com diferentes tempos de leitura (24, 48 e 72 horas) nos pacientes com APLV IgE mediada e nas doenças eosinofílicas do trato digestório.

2.2.3. Avaliar a melhora clínica e endoscópica dos pacientes com DETD após restrição dietética sugerida pelo TCA 
Casuística e Métodos 


\section{CASUÍSTICA E MÉTODOS}

\subsection{Casuística}

Neste estudo de corte transversal foram avaliados 45 pacientes e 9 controles entre 2008 a 2010.Todos os pacientes foram incluídos em um protocolo padronizado de avaliação clínica que contempla história detalhada dos sintomas, antecedentes pessoais e familiares de atopia (anexo B). Foram avaliados pacientes em seguimento no Ambulatório de Alergia Alimentar da Unidade de Alergia e Imunologia do ICr-HCFMUSP com idade entre 2 anos e 18 anos 11 meses e 29 dias, com diagnóstico definitivo de alergia à proteína do leite de vaca lgE mediada ou com doenças eosinofílicas do trato digestivo desencadeada pelo leite.

- Grupo 1: crianças com APLV IgE mediada diagnosticadas pelo teste de provocação oral duplo cego placebo controlado

- Grupo 2: crianças com Esofagite ou Enterocolite Eosinofílica diagnosticadas através da biópsia com contagem $\geq 15$ eosinófilos/cga para EoE e $\geq 20$ eosinófilos/cga para enterocolite eosinofílica com sintomas associados à ingestão de leite de vaca.

- Grupo 3 : crianças com história sugestiva de APLV e com diagnóstico excluído após teste de provocação aberto ou TDCPC com leite de vaca (Grupo Controle).

Os critérios de exclusão estabelecidos foram:

- Crianças com APLV e anafilaxia recente (intervalo de tempo menor que 1 ano) após a ingestão do leite de vaca;

- Pacientes em uso de corticoterapia sistêmica ou inalatória e deglutido em doses correspondentes a $\geq 800 \mathrm{mcg}$ de Budesonida nos últimos quinze dias;

- Pacientes em uso de anti-histamínicos orais nos últimos 7 dias; 
- Paciente em uso de imunossupressor sistêmico nos últimos 15 dias;

- Pacientes com lesões agudas e exsudadas no local da aplicação do teste e lou em uso de imunossupressores tópicos locais; e/ou imunomoduladores tópicos nos últimos 7 dias;

- Pacientes com impossibilidade de retorno para leitura do teste

O diagnóstico de alergia alimentar foi definido quando presente todos os seguintes critérios:

\section{Alergia à Proteína do Leite de Vaca IgE mediada (Grupo 1)}

- Anamnese sugestiva, mostrando a relação entre o aparecimento de sintomas da pele e/ou sistema digestivo e/ou sistema respiratório em até 2 horas após a ingestão confirmada do leite de vaca;

- História familiar de atopia em pelo menos um dos pais ou irmãos;

- Presença de $\lg E$ específica realizada através do teste cutâneo de leitura imediata para leite de vaca e frações, considerado positivo quando houver presença de pápula superior ou igual a $3 \mathrm{~mm}$. Outra metodologia aceita foi a realização da pesquisa de $\lg E$ específica in vitro através do ImmunoCAP®, sendo considerados significantes os resultados $\geq 3,5 \mathrm{KU} / \mathrm{L}$.

- Teste de provocação duplo cego placebo controlado positivo para leite de vaca.

\section{Doenças Eosinofílicas do Trato Digestório (DETD) (Grupo 2)}

- Na esofagite eosinofílica a anamenese é sugestiva de história de doença do refluxo gastroesofágico de difícil controle e não responsiva à terapêutica habitual (inibidor de próton, procinéticos). Dificuldade na ingestão de alimentos, vômitos, refluxo e dores abdominais. Em adolescentes podem ser referidos disfagia e impactação de alimentos. Na gastroenteropatia eosinofílica a anamnese é sugestiva de diarréia, dor abdominal, às vezes associada a baixo ganho ponderoestatural; 
- Biópsia nos locais acometidos com contagem de $\geq 15$ eosinófilos/cga para EoE e $\geq 20$ eosinófilos/cga para Enterite eosinofílica

\subsection{Avaliação Laboratorial}

Foi realizada avaliação laboratorial antes da indicação do teste de contato atópico em relação a:

3.2.1 Dosagem de IgE sérica total; foi realizada a coleta de sangue em tubo contendo gel o qual foi analisado por nefelometria. Estes testes foram realizados no Laboratório Central do HCFMUSP.

\subsubsection{Dosagem de IgE específica in vitro (ImmunoCAP $®$ ) para os} seguintes alérgenos: leite de vaca, caseína, a-lactoalbumina, $\beta$ lactoglobulina. Todos os testes foram realizados no Laboratório de Investigação Médica-60 da Faculdade de Medicina da USP. Esta dosagem foi realizada através do ImmunoCAP, um ensaio imunoenzimático e com fluorescência. As concentrações obtidas foram expressas em KU/L (Leimgruber et al, 1989; Borelli et al, 1990).

3.2.3 Prick Teste para pesquisa de IgE específica in vivo foi realizado na Unidade de Alergia e Imunologia do Instituto da Criança por médicos treinados sob supervisão. Em todos os pacientes foi utilizada a região volar do antebraço, onde foi aplicada uma gota do extrato de leite de vaca e frações (caseína, $\alpha$-lactoalbumina e $\beta$-lactoglobulina) uma gota de controle positivo (histamina) e outra gota de controle negativo. Foi realizada uma pequena puntura com puntor padronizado e estéril para cada extrato, aguardando-se cerca de 15 minutos para leitura. Considerou-se positivo resultados de pápulas $\geq 3 \mathrm{~mm}$.

\subsubsection{Teste de provocação oral duplo cego placebo controlado} (TPODCPC) foi realizado no Hospital Dia do Instituto da Criança, sendo adotada técnicas padronizada pela Unidade de Alergia e Imunologia e baseada nas descrições de Willians e Bock (1999). O teste foi realizado 
em ambiente hospitalar, com duração de aproximadamente dez horas e foi dividido em dois períodos: manhã e tarde. Nestes períodos o paciente recebeu volumes fixos de $60 \mathrm{~mL}$ em intervalos de 15 a 30 minutos até completar $300 \mathrm{~mL}$. No período em que recebeu o leite de vaca, foram administradas doses crescentes destes $(5,10,15,20,25,25 \mathrm{~mL})$ sempre adicionadas ao veículo para perfazer um volume total de $60 \mathrm{~mL}$. É importante ressaltar que o veículo utilizado mascarou o sabor e o aspecto do leite de vaca e que somente um profissional não envolvido diretamente como paciente soube qual dos períodos continha o leite ou apenas o veículo. Além disto, utilizou-se leite com baixo teor de lactose para excluir manifestações clínicas relacionadas à intolerância à lactose. Ao fim do teste, caso o resultado tivesse sido negativo, o paciente realizou uma fase aberta onde foi ingerido o leite de vaca aguardando-se um período de pelo menos 1 hora ainda em ambiente hospitalar. Ao apresentar qualquer sintoma durante o teste, o paciente era avaliado pelo médico responsável, que decidiu quais condutas seriam tomadas inclusive medicação e interrupção do teste, sendo todo o procedimento registrado em formulário específico (Gushken, 2009).

3.2.5 Endoscopia Digestiva Alta: para o diagnóstico de esofagite eosinofílica foi realizado no Serviço de Endoscopia Pediátrica do Instituto da Criança do Hospital das Clínicas-HCFMUSP com os pacientes sob sedação ou anestesia geral. Foram utilizados aparelhos da marca PENTAX E62900 ou FUJINON modelo E6590WR. Nos pacientes com sinais endoscópicos sugestivos de Esofagite Eosinofílica (mucosa espessada, esbranquiçada, estrias longitudinais, pontos de fibrina, constrições anelares com subestenose, foram realizadas biopsia em 2 segmentos (distal e proximal), com coleta de 2 fragmentos no mínimo para análise anatomopatológica sendo considerado como esofagite eosinofílica a presença na microscopia de $\geq 15$ eosinófilos/cga. Nos pacientes que apresentaram TCA positivo para leite, após 3 meses de 
dieta de exclusão foi repetida a endoscopia com biópsia para avaliar se houve melhora endoscópica.

3.2.6 Colonoscopia: foi realizado no Serviço de Endoscopia Pediátrica do Instituto da Criança do Hospital das Clínicas-HCFMUSP com os pacientes sob sedação ou anestesia geral.Foram utilizados aparelhos da marca Olympus modelo PCF $160 \mathrm{AL}$. Todos os pacientes foram previamente submetidos a preparo do cólon com dieta sem resíduos e solução manitol a $10 \%$ sendo realizado lavagem com solução glicerinada quando necessário.Foram examinados todos os segmentos cólicos e íleo terminal onde foram realizadas biopsias seriadas. Quando há presença de hiperplasia linfóide na macroscopia, no mínimo 4 segmentos (cólon direito, cólon esquredo, íleo terminal, reto sigmóide são encaminhados para anátomo patológico. Nos pacientes que apresentaram TCA positivo para leite, após 3 meses de dieta de exclusão foi repetida a colonoscopia com biópsia para avaliar se houve melhora endoscópica.

\subsection{Avaliação do Teste de Contato Atópico}

\subsubsection{Orientações do teste}

Aos pacientes que realizaram o teste foram explicadas as seguintes recomendações:

$>$ Os pacientes foram orientados a suspender atividades físicas durante a realização do teste

> Foi recomendado banho rápido, evitando o contato direto da água com o dorso durante os dias da aplicação do teste

Os exames foram preferencialmente agendados às segundas-feiras no Instituto da Criança-Hospital das Clínicas para que as leituras não ocorressem aos finais de semana. No dia anterior ao teste, a pesquisadora telefonava para os pacientes para confirmação do teste e reforçava as orientações pré teste. Alguns pacientes foram dispensados após este 
contato por relatarem impossibilidade de comparecer nos dias solicitados, ou por apresentarem algum sinal ou sintoma que pudessem interferir na interpretação dos resultados.

\subsubsection{Realização do teste}

Os pacientes foram recepcionados na sala de testes alérgicos no Instituto da Criança. Todos os testes foram realizados pela mesma pesquisadora. O protocolo padronizado com dados clínicos, antecedentes de atopia pessoal e familiar foi preenchido, assim como o termo de consentimento livre esclarecido (anexo F). A pesquisadora não tinha ciência do resultado do TPODCPC realizados nos pacientes IgE mediados para evitar interpretação tendenciosa do teste.

O teste de contato atópico foi realizado em todas as crianças usando leite fresco e a proteína do leite liofilizada purificada contida em Kit comercial (IPI - ASAC Espanha). Os extratos comerciais foram armazenados em geladeira, com controle de temperatura, localizada na sala de procedimentos. A validade dos extratos foi assegurada conforme as instruções do fabricante. O leite fresco foi fornecido pela nutricionista do hospital em um copo plástico, no momento do teste. A proteína do leite foi purificada e liofilizada na concentração de $20 \%$ de proteína e misturada em $80 \mathrm{~g}$ de vaselina e fornecidas em seringas pelo fabricante (Canani et al, 2007). O leite de vaca in natura é utilizado na quantidade de uma gota (50ul) contendo $3,5 \%$ gordura.

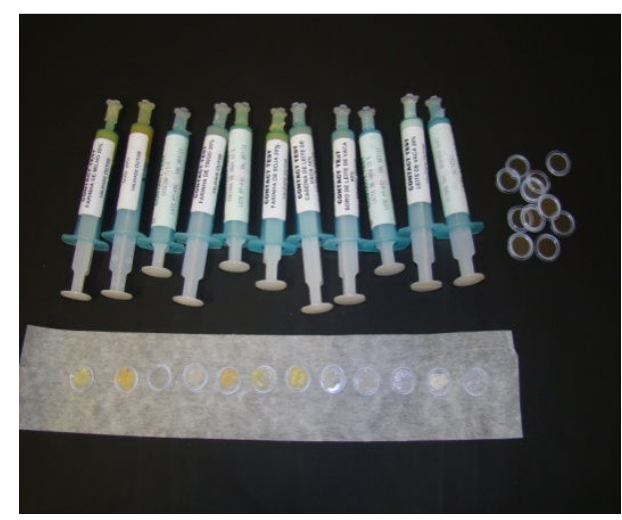

Figura1- Material utilizado no TCA 
Materiais utilizados para a realização do teste:

- Micropore Nexcare 3M

- Câmara de plástico (Jesenak et al, 2008; Ronchetti et al, 2008) 12mm (IPI-ASAC Brasil) (Niggemann et al, 2002; Turjanmaa et al, 2006)

- Algodão, Álcool 70\%, Papel de filtro

- Máquina Fotográfica Sony Modelo DSC-H50 9.1 Mega Pixels

Preparação: O teste foi preparado no momento da sua aplicação utilizando câmara de plástico de $12 \mathrm{~mm}$ de diâmetro onde foi depositado o alérgeno em toda a sua superfície. A vaselina, além de veículo, foi usada também como controle negativo. O papel de filtro foi embebido com o leite de vaca in natura. $\mathrm{O}$ dorso do paciente foi fotografado para registrar a integridade da pele anterior ao teste. Foi realizada a limpeza do dorso e procedida a fixação das câmaras, que estão aderidas a um adesivo hipoalergênico. $O$ paciente foi orientado a não molhar o local e evitar atividades de esforço ou que prejudicasse a aderência do teste. $O$ teste foi aplicado em duplicada com os mesmos alérgenos para que duas avaliações sejam feitas. $O$ tempo de leitura foi de 24 horas para um dos conjuntos dos alérgenos e de 48 horas para o outro conjunto. A leitura foi realizada após 20 minutos da remoção dos alérgenos. A leitura final foi feita com 72 horas de acordo com as recomendações do European Task Force na Dermatite Atópica (ETFAD) o resultado foi aferido em escala de cruzes sendo considerado positivo: + eritema com infiltração; ++ eritema e poucas pápulas; +++ eritema e muitas pápulas; ++++ eritema e vesículas.Todos os testes foram lidos pelo mesmo pesquisador e mais um observador treinado. Para fins de análise estatística os resultados das intensidades das reações cutâneas foram convertidos em escalas numéricas. As recomendações do EuropeanTask Force na Dermatite Atópica (EDTA). 


\section{Quadro 3. Leitura do Teste de Contato Atópico- European Task Force on Atopic Dermatitis (ETFAD)}

\begin{tabular}{|l|l|}
\hline \multicolumn{1}{|c|}{ Reação Cutânea } & Interpretação \\
\hline Ausente & Negativo (-) \\
\hline Somente eritema & Duvidoso(?) \\
\hline Eritema e infiltração & Positivo (+) \\
\hline Eritema e algumas pápulas & Positivo (++) \\
\hline Eritema e várias pápulas & Positivo (+++) \\
\hline Eritema e vesículas & Positivo (++++) \\
\hline Adaptado de Turjanmaa K et al, 2006 \\
\hline
\end{tabular}

\subsection{ASPECTOS ÉTICOS}

O Projeto deste estudo foi apresentado à Comissão de Ética e Pesquisa do Instituto da Criança do HCFMUSP e pela Comissão de Ética para Análise de Projetos de Pesquisa (CAPPesq e HCFMUSP) e foi aprovado sob número 0995/07. Os responsáveis pelos pacientes foram informados sobre o estudo, métodos e necessidade de exames laboratoriais (coleta de sangue e testes cutâneos padronizados), sendo os pacientes incluídos no estudo apenas após a anuência dos pais com os termos de consentimento livre e esclarecido, de acordo com as normas do Comitê de Pesquisa e Ética desta instituição (anexo A). 


\subsection{ANÁLISE ESTATÍSTICA}

As análises foram realizadas por meio do software estatístico SPSS 13.0, adotando-se como nível de significância 5\%. A variável contínua (idade) nos 3 grupos foi descrita através de suas medianas. As Variáveis nominais (sexo, positividade do TCA) foram descritas através de suas freqüências e comparadas através do teste de Fisher. A concordância dos resultados nos grupos 1 e 2 nos 3 tempos foram analisadas 2 a 2 através do teste de McNemar.Os valores preditivos positivos do TCA foi calculado usando-se o software estatístico Graph Pad Instat 3.01 
Resultados 


\section{RESULTADOS}

\subsection{Caracterização da Casuística}

Neste estudo, foram incluídos 45 pacientes e 9 controles (38 M: $16 \mathrm{~F}$ ). Esta casuística foi composta pelo grupo dos pacientes com alergia a proteína do leite de vaca IgE mediada (Grupo1) com 15 pacientes. O grupo das doenças eosinofílicas do trato gastrintestinal (Grupo 2) composto por 26 pacientes com esofagite eosinofílica e $4 \mathrm{com}$ enteropatia eosinofílica foi o mais numeroso $(n=30)$. O grupo controle (grupo 3$)$ foi composto por 9 crianças com diagnóstico excluído de alergia à proteína do leite de vaca. Nos pacientes com APLV (grupo1), 14 apresentavam manifestações cutâneas, 11 respiratórias, 10 gastrintestinais e 3 sistêmicas. Nos pacientes com DETD, 24 apresentavam queixa de dor epigástrica, seguida por vômitos em 23 pacientes, 10 com baixo ganho ponderal, 7 com impactação alimentar e 4 com diarréia. 
Tabela 1. Dados demográficos e presença de atopia pessoal e familiar dos pacientes dos grupos 1, 2, 3

\begin{tabular}{|c|c|c|c|c|}
\hline Grupo & $\begin{array}{l}\text { Sexo } \\
\text { (M/F) }\end{array}$ & $\begin{array}{c}\text { Idade na } \\
\text { realização do } \\
\text { TCA } \\
\text { Anos } \\
\text { (Mediana) } \\
\text { (v.min-v.max) }\end{array}$ & $\begin{array}{l}\text { Presença de } \\
\text { atopia pessoal } \\
(\%)\end{array}$ & $\begin{array}{l}\text { Presença de } \\
\text { atopia familiar } \\
\text { (\%) }\end{array}$ \\
\hline $\begin{array}{c}\text { Grupo } 1 \\
n=15\end{array}$ & $10 / 5$ & $\begin{array}{c}4,4 \\
(2-11,5)\end{array}$ & $80 \%$ & $33,3 \%$ \\
\hline $\begin{array}{c}\text { Grupo } 2 \\
n=30\end{array}$ & $21 / 9$ & $\begin{array}{c}8,8 \\
(2,5-13,9)\end{array}$ & $93,3 \%$ & $46,6 \%$ \\
\hline $\begin{array}{c}\text { Grupo } 3 \\
n=9\end{array}$ & $7 / 2$ & $\begin{array}{c}6,2 \\
(2,0-15,6)\end{array}$ & $44,4 \%$ & $22,2 \%$ \\
\hline
\end{tabular}

Tabela 2. Concentração sérica de IgE total e específica para leite e/ ou frações e teste de provocação oral duplo cego placebo controlado dos pacientes dos grupos $1,2,3$

\begin{tabular}{|c|c|c|c|c|}
\hline Grupo & $\begin{array}{c}\text { Pacientes } \\
\text { com lgE } \\
\text { total } \\
(\geq 100 \mathrm{kU} / \mathrm{L}) \\
(\%)\end{array}$ & $\begin{array}{c}\text { Pacientes } \\
\text { com Immuno } \\
\text { CAP® } \geq \\
\text { 3,5kU/L para } \\
\text { LV e/ou } \\
\text { frações } \\
(\%)\end{array}$ & $\begin{array}{c}\text { Pacientes } \\
\text { com Prick } \\
\text { Test } \\
\text { LV e/ou } \\
\text { frações } \\
(\geq 3 \mathrm{~mm}) \\
(\%)\end{array}$ & $\begin{array}{c}\text { TPODCPC } \\
\mathbf{N}^{\circ} \\
\text { realizados/ } \\
\text { positivos }\end{array}$ \\
\hline $\begin{array}{c}\text { Grupo } 1 \\
n=15\end{array}$ & $\begin{array}{c}14 \\
(93,3 \%)\end{array}$ & $\begin{array}{c}11 \\
73,3 \%\end{array}$ & $\begin{array}{c}15 \\
100 \%\end{array}$ & $15 / 15$ \\
\hline $\begin{array}{c}\text { Grupo } 2 \\
n=30\end{array}$ & $\begin{array}{c}20 \\
(66,6 \%)\end{array}$ & $\begin{array}{c}8 \\
(26,6 \%)\end{array}$ & $\begin{array}{c}15 \\
(50 \%)\end{array}$ & $\mathbf{N R}^{*}$ \\
\hline $\begin{array}{l}\text { Grupo3 } \\
n=9\end{array}$ & $\begin{array}{c}4 \\
(44,4 \%)\end{array}$ & 0 & 0 & $7 / 0$ \\
\hline
\end{tabular}

${ }^{*}$ Nenhum paciente realizou 


\subsection{Resultados do Teste de Contato Atópico}

A freqüência de positividade do TCA com o extrato de leite de vaca a $20 \%$ e/ou leite de vaca in natura nos tempos de leitura de 24, 48 e 72 horas nos pacientes com APLV IgE mediada foi:

$$
\begin{aligned}
& -24 \text { horas }=46,8 \% \\
& -48 \text { horas }=86,7 \% \\
& -72 \text { horas }=86,7 \%
\end{aligned}
$$

Este grupo foi composto por 7 pacientes com dermatite atópica os quais todos apresentaram TCA positivo. Enquanto dos 8 pacientes sem dermatite atópica, 6 deles mostraram positividade no TCA.

No grupo das doenças eosinofílicas do trato digestório a freqüência de positividade do TCA com o extrato de leite de vaca a $20 \%$ e/ou leite de vaca in natura nos tempos de leitura de 24, 48 e 72 horas foi:

$$
\begin{aligned}
& -24 \text { horas }=23,3 \% \\
& -48 \text { horas }=80 \% \\
& -72 \text { horas }=66,7 \%
\end{aligned}
$$

No grupo 3 ( grupo controle) todos os pacientes foram não reativos no TCA. A tabela 3 e 4 ilustram a comparação entre o extrato de leite de vaca a $20 \%$ e leite de vaca in natura em relação a freqüência de positividade do TCA nos pacientes com APLV IgE mediada e na DETD.

Tabela 3. Comparação entre o extrato de leite de vaca a $20 \%$ e o leite de vaca in natura em relação a freqüência de positividade do TCA nos pacientes com APLV IgE mediada, nos 3 tempos de leitura avaliados

\begin{tabular}{clcl}
\hline $\begin{array}{c}\text { Tempo (horas) } \\
\mathrm{N}=15\end{array}$ & $\begin{array}{l}\text { LV20\% } \\
\mathrm{n}(\%)\end{array}$ & $\begin{array}{c}\text { LV in natura } \\
\mathrm{n}(\%)\end{array}$ & Fisher $(\mathrm{p})$ \\
\hline 24 & $6(46,2)$ & $2(13,3)$ & 0,486 \\
48 & $12(80)$ & $7(46,7)$ & 1,000 \\
72 & $12(80)$ & $6(40)$ & 1,000 \\
\hline
\end{tabular}


Não foi encontrada diferença estatisticamente significante entre as freqüências de positividade do TCA entre o leite in natura e o extrato de leite de vaca a $20 \%$ no grupo das APLV IgE mediadas, nos 3 tempos de leitura avaliados.

Tabela 4. Comparação entre o extrato de leite de vaca a $20 \%$ e o leite de vaca in natura em relação a freqüência de positividade do TCA em pacientes com Doenças Eosinofílicas do Trato Digestório

\begin{tabular}{cccc}
\hline $\begin{array}{c}\text { Tempo (horas) } \\
\mathrm{N}=30\end{array}$ & $\begin{array}{c}\text { LV20\% } \\
\mathrm{n}(\%)\end{array}$ & $\begin{array}{c}\text { LV in natura } \\
\mathrm{n}(\%)\end{array}$ & Fisher $(\mathrm{p})$ \\
\hline 24 & $6(20)$ & $4(13,3)$ & 0,730 \\
48 & $22(73,3)$ & $15(50)$ & 0,110 \\
72 & $18(60)$ & $15(50)$ & 0,604
\end{tabular}

Não foi encontrada diferença estatisticamente significante entre as freqüências de positividade do TCA entre o leite in natura e o extrato de leite de vaca a $20 \%$ no grupo das Doenças Eosinofílicas do Trato Digestório, nos 3 tempos.

A tabela 5 apresenta a avaliação da concordância entre os tempos de leitura $24,48,72$ horas do TCA com o extrato de leite de vaca a $20 \%$ e/ou leite de vaca in natura nos pacientes com APLV IgE mediada.

Tabela 5. Concordância entre os tempos de leitura do TCA com o extrato de leite de vaca a $20 \%$ e lou leite de vaca in natura nos pacientes com APLV IgE mediada

\begin{tabular}{ccc}
\hline $\begin{array}{c}\text { Grupo } \\
\mathrm{n}=15\end{array}$ & $\begin{array}{c}\text { Tempo de leitura } \\
\text { (horas) }\end{array}$ & McNemar (p) \\
\hline APLV IgE mediada & $24 \times 48$ & 0,031 \\
& $24 \times 72$ & 0,031 \\
& $48 \times 72$ & 1,000 \\
\hline
\end{tabular}


A diferença encontrada entre os tempos $24 \times 48$ e $24 \times 72$ horas foram estatisticamente significante (McNemar $p=0,031)$. Entretanto a diferença encontrada entre $48 \times 72$ horas não foi estastisticamente significante (Mc Nemar $p=1,000)$.

A tabela 6 apresenta a avaliação da concordância entre os tempos de leitura $24,48,72$ horas do TCA com o extrato de leite de vaca a $20 \%$ e /ou leite de vaca in natura nos pacientes com doenças eosinofílicas do trato digestório.

Tabela 6. Concordância entre os tempos de leitura do TCA com o extrato de leite de vaca a $20 \%$ e lou leite de vaca in natura nos pacientes com doenças eosinofílicas do trato digestório

\begin{tabular}{lcc}
\hline $\begin{array}{c}\text { Grupo } \\
\mathrm{n}=30\end{array}$ & $\begin{array}{c}\text { Tempo de leitura } \\
\text { (horas) }\end{array}$ & McNemar (p) \\
\hline $\begin{array}{l}\text { Doenças } \\
\text { Eosinofílicas do }\end{array}$ & $24 \times 48$ & 0,000 \\
Trato Digestório & $24 \times 72$ & 0,001 \\
& $48 \times 72$ & 0,125 \\
\hline
\end{tabular}

A diferença encontrada entre os tempos $24 \times 48$ e $24 \times 72$ horas foram estatisticamente significante (McNemar $p=0,000$ e $p=0,001$, respectivamente). Entretanto a diferença encontrada entre $48 \times 72$ horas não foi estastisticamente significante (Mc Nemar $p=0,125)$.

A tabela 7 apresenta a avaliação da concordância entre os tempos de leitura $24,48,72$ horas do TCA com o extrato de leite de vaca a $20 \%$ e nos pacientes com APLV IgE mediada. 
Tabela 7. Avaliação da concordância entre os tempos de leitura do TCA com o extrato de leite de vaca a $20 \%$ nos pacientes com APLV IgE mediada

\begin{tabular}{ccc}
$\begin{array}{c}\text { Grupo } \\
\mathrm{n}=15\end{array}$ & $\begin{array}{c}\text { Tempo de leitura } \\
\text { (horas) }\end{array}$ & McNemar (p) \\
\hline \multirow{2}{*}{ APLV IgE mediada } & $24 \times 48$ & 0,031 \\
& $24 \times 72$ & 0,031 \\
& $48 \times 72$ & 1,000 \\
\hline
\end{tabular}

A diferença encontrada entre os tempos $24 \times 48$ e $24 \times 72$ horas foram estatisticamente significante (McNemar $p=0,031)$. Entretanto a diferença encontrada entre $48 \times 72$ horas não foi estastisticamente significante (Mc Nemar $p=1,000)$.

A tabela 8 apresenta a avaliação da concordância entre os tempos de leitura $24,48,72$ horas do TCA com o extrato de leite de vaca a $20 \%$ nos pacientes com doenças eosinofílicas do trato digestório.

Tabela 8. Avaliação da concordância entre os tempos de leitura do TCA com o extrato de leite de vaca a 20 \% nos pacientes com doenças eosinofílicas do trato digestório

\begin{tabular}{lcc}
\hline $\begin{array}{c}\text { Grupo } \\
\mathrm{n}=30\end{array}$ & $\begin{array}{c}\text { Tempo de leitura } \\
\text { (horas) }\end{array}$ & McNemar (p) \\
\hline $\begin{array}{c}\text { Doenças } \\
\text { Eosinofílicas do } \\
\text { Trato Digestório }\end{array}$ & $24 \times 48$ & 0,000 \\
& $24 \times 72$ & 0,002 \\
& $48 \times 72$ & 0,125 \\
\hline
\end{tabular}

A diferença encontrada entre os tempos $24 \times 48$ e $24 \times 72$ horas foram estatisticamente significante (McNemar $p=0,000$ e $p=0,002$, respectivamente). Entretanto a diferença encontrada entre $48 \times 72$ horas não foi estastisticamente significante (Mc Nemar $p=0,125)$. 
A tabela 9 apresenta a avaliação da concordância entre os tempos de leitura $24,48,72$ horas do TCA com o extrato de leite de vaca in natura e nos pacientes com APLV IgE mediada.

Tabela 9. Avaliação da concordância entre os tempos de leitura do TCA com o leite in natura nos pacientes com APLV IgE mediada

\begin{tabular}{ccc}
\hline $\begin{array}{c}\text { Grupo } \\
\mathrm{n}=15\end{array}$ & $\begin{array}{c}\text { Tempo de leitura } \\
\text { (horas) }\end{array}$ & McNemar (p) \\
\hline APLV IgE mediada & $24 \times 48$ & 0,063 \\
& $24 \times 72$ & 0,125 \\
& $48 \times 72$ & 1,000 \\
\hline
\end{tabular}

A diferença encontrada entre os tempos $24 \times 48,24 \times 72$ e $48 \times 72$ não foi estatisticamente significante (McNemar $p=0,063, p=0,125, p=1,000$, respectivamente).

A tabela 10 apresenta a avaliação da concordância entre os tempos de leitura $24,48,72$ horas do TCA com o extrato de leite de vaca in natura nos pacientes com doenças eosinofílicas do trato digestório.

Tabela 10. Avaliação da concordância entre os tempos de leitura do TCA como leite in natura nos pacientes com doenças eosinofílicas do trato digestório

\begin{tabular}{lcc}
\hline $\begin{array}{c}\text { Grupo } \\
\mathrm{n}=30\end{array}$ & $\begin{array}{c}\text { Tempo de leitura } \\
\text { (horas) }\end{array}$ & McNemar (p) \\
\hline $\begin{array}{l}\text { Doenças } \\
\begin{array}{l}\text { Eosinofilicas do } \\
\text { Trato Digestório }\end{array}\end{array}$ & $24 \times 48$ & 0,003 \\
& $24 \times 72$ & 0,003 \\
& $48 \times 72$ & 1,000 \\
\hline
\end{tabular}

A diferença encontrada entre os tempos $24 \times 48$ e $24 \times 72$ horas foram estatisticamente significante (McNemar $p=0,003)$. Entretanto a diferença encontrada entre $48 \times 72$ horas não foi estastisticamente significante (Mc Nemar $p=1,000)$. 
As reações adversas ocorridas durante a aplicação e leitura do TCA estão descritas na tabela 11.

Tabela 11. Descrição das reações adversas ocorridas durante a aplicação e leituras do TCA nos grupos 1 e 2

\begin{tabular}{c|l}
\hline Grupo & \multicolumn{1}{|c}{ Reações adversas } \\
\hline 1 & $\begin{array}{l}\text { Hiperemia e Prurido após 26 horas da aplicação da câmara com } \\
\text { leite de vaca in natura }\end{array}$ \\
\hline 1 & Hiperemia na face e micropápulas nas costas e no tórax \\
\hline 1 & Prurido no local da aplicação da câmara \\
\hline 2 & $\begin{array}{l}\text { Prurido na garganta e no local da aplicação câmara após 24-48 } \\
\text { horas }\end{array}$ \\
\hline 2 & Obstrução nasal e espirros após 46 horas \\
\hline & $\begin{array}{l}\text { Dermatite de contato irritativa pelo micropore e prurido no local } \\
\text { da aplicação }\end{array}$ \\
\hline
\end{tabular}

4.3 Avaliação da contribuição da restrição dietética sugerida pelo TCA na melhora clínica e endoscópica dos pacientes com Doenças Eosinofílicas do Trato Digestório (DETD) após exclusão do leite de vaca identificado através do teste de contato atópico

Considerando os trinta pacientes com DETD, vinte deles $(66,6 \%)$ apresentaram positividade na leitura final de 72 horas do TCA para o leite de vaca. Estes pacientes foram submetidos à dieta de exclusão deste alimento e após 3 meses foram avaliados em relação aos sintomas clínicos e à contagem do número de eosinófilos, sendo que treze (65\%) deles apresentaram melhora clínica e endoscópica e dezesseis (80\%) apresentaram melhora clínica. 
Tabela 12. Descrição da melhora clínica e histológica em 20 pacientes com DETD com TCA positivo após 3 meses de exclusão do leite

\begin{tabular}{|c|c|c|c|c|}
\hline $\begin{array}{l}\text { Número } \\
\text { dos } \\
\text { Pacient } \\
\text { es }\end{array}$ & $\begin{array}{l}\text { Sintomas clínicos } \\
\text { Pré Dieta } \\
\text { Exclusão }\end{array}$ & $\begin{array}{c}N^{0} \\
\text { eosinófilos/ } \\
\text { cga na } \\
\text { biópsia } \\
\text { Pré dieta } \\
\text { restrita de LV }\end{array}$ & $\begin{array}{c}\mathrm{N}^{0} \\
\text { eosinófilos/ } \\
\text { cga na } \\
\text { biopsia } \\
\text { Pós dieta } \\
\text { restrita de LV }\end{array}$ & $\begin{array}{l}\text { Melhora clínica pós } \\
\text { dieta restrita de LV }\end{array}$ \\
\hline 18 & Vômito e dor abdominal & 36 & 20 & Não \\
\hline 20 & Epigastralgia e náusea & 30 & $2^{*}$ & Sim \\
\hline 21 & Epigastralgia e vômito & 22 & $4^{*}$ & Sim \\
\hline 23 & Dor abdominal e nausea & 20 & $8^{*}$ & Sim \\
\hline 25 & $\begin{array}{c}\text { Dor abdominal,vômito e } \\
\text { disfagia }\end{array}$ & 26 & 23 & Não \\
\hline 26 & $\begin{array}{l}\text { Vômito,disfagia, dor } \\
\text { abdominal perda peso, e } \\
\text { alimentação lenta }\end{array}$ & 40 & $0^{*}$ & Sim \\
\hline 29 & Epigastralgia e vômito & 50 & 21 & Não \\
\hline 30 & Vômito e impactação & 44 & 40 & Sim \\
\hline 31 & Epigastralgia e dor abdominal & 30 & $2^{*}$ & Sim \\
\hline 33 & $\begin{array}{l}\text { Epigastralgia,vômito,disfagia } \\
\text { perda de peso e impactação }\end{array}$ & 38 & $10^{*}$ & Sim \\
\hline 35 & $\begin{array}{l}\text { Dorabdominal,vômito, } \\
\text { alimentação lenta }\end{array}$ & 36 & 18 & Sim \\
\hline 36 & $\begin{array}{c}\text { Impactação,dor abdominal e } \\
\text { vômito }\end{array}$ & 56 & 50 & Não \\
\hline 37 & Vômito e dor abdominal & 30 & $10^{*}$ & Sim \\
\hline 38 & $\begin{array}{l}\text { Epigastralgia,vômito e } \\
\text { impactação }\end{array}$ & 25 & $6^{*}$ & Sim \\
\hline 39 & Vômito e dor abdominal & 20 & $0^{*}$ & Sim \\
\hline 40 & Dor abdominal e impactação & 20 & $1^{*}$ & Sim \\
\hline 42 & Diarréia & 44 & $12^{*}$ & Sim \\
\hline 43 & Dor abdominal e diarréia & 50 & $10^{*}$ & Sim \\
\hline 44 & Diarréia & 40 & 30 & Sim \\
\hline 45 & Diarréia, dor abdominal & 40 & $12^{*}$ & Sim \\
\hline
\end{tabular}

${ }^{*}$ Pacientes com melhora histológica $<15$ eosinófilos/cga para EoE e $<20$ eosinófilos/cga para Enterite Eosinofílica 
A mediana do número de eosinófilos na biópsia realizada antes da instituição da dieta de eliminação do leite foi de 36 eosinófilos/cga (20-56 eosinófilos/cga) e após a dieta foi de 10 (0-50 eosinófilos/cga). A comparação entre as medianas foi estatisticamente significante, com $p<0,001$. 
Discussão 


\section{Discussão}

A prevalência de alergia alimentar têm aumentado em vários países, nos últimos anos (Sampson, 1999; Braunun e Lukacs, 2008). Entre os possíveis alimentos envolvidos neste processo, se destaca o leite de vaca por ser um dos primeiros a ser introduzido na dieta da criança, muitas vezes, mesmo durante o aleitamento materno (Benhamou et al, 2009). Trata-se de um alimento que apresenta grande importância nutricional, mas também é um dos principais alérgenos na faixa etária pediátrica, principalmente nos primeiros anos de vida, estando a alergia alimentar a esse alimento presente em cerca de 1,5 a $5 \%$ das crianças nos primeiros anos de vida (Bock, 1987; Sampson 1999; Nowak- Wegrzyn e Sampson, 2006).

A Unidade de Alergia e Imunologia do Instituto da Criança do HCFMUSP possui um ambulatório de alergia alimentar onde foram avaliados cerca de 200 pacientes com AA, destes 80\% receberam confirmação diagnóstica de APLV, ressaltando a importância deste alérgeno. Nos últimos anos tem ocorrido um aumento crescente no diagnóstico de pacientes com esofagite eosinofílica neste ambulatório. O aumento na prevalência da EoE também está sendo relatado por outros autores em diversos países (Liacouras et al, 2011, Furuta et al, 2007; Spergel ,2007).

Desde a criação do ambulatório de alergia alimentar, em 2003, verificou-se a necessidade de implantar o TPODCPC, considerado o padrão ouro para o diagnóstico de alergia alimentar. Entretanto ao longo destes anos, constataram-se as dificuldades de sua realização, fato este já referido na literatura por vários autores (Niggemann \& Beyer, 2007, Nowak- Wegrzyn et al, 2009). Este exame demanda tempo, pessoal altamente treinado, além de local adaptado ao atendimento de reações graves. Outra limitação é a dificuldade da realização em crianças menores e em pacientes com manifestações clínicas tardias decorrentes de mecanismo misto ou não lgE mediado. Por todos estes fatores, houve a busca por outros testes diagnósticos que poderiam ser úteis, e neste contexto o TCA passou a ser 
uma alternativa, não para substituir o TPODCPC, mas para em conjunto com dados clínicos e laboratoriais, auxiliar no diagnóstico da AA.

Este fato foi enfatizado quando se estabeleceu na literatura a associação de alérgenos alimentares e EoE, trazendo a necessidade da identificação destes através de testes alérgicos (Spergel, 2007).

Todos os fatores acima motivaram a realização deste estudo, que embora representasse um desafio, poderia auxiliar no diagnóstico de pacientes com doenças eosinofílicas do trato digestório, já que as formas IgE mediadas são contempladas com vários testes já padronizados.

A definição da casuística contemplou alguns aspectos. Em relação à escolha dos grupos APLV e controle alguns comentários devem ser feitos. O grupo APLV IgE mediada foi incluido pelo fato de que na literatura, o TCA já havia sido utilizado por Keskin et al (2005) para avaliar se este teste contemplaria também manifestações clínicas com mecanismos lgE mediados. Na experiência finlandesa, isto ocorreu com um percentual não desprezível de pacientes portadores de DA, que podem ter como mecanismo fisiopatológico o $\mathrm{lg} E$ mediado e também o mecanismo misto (Isolauri e Turnjamaa,1996).

Desde o início da pesquisa surgiu o interesse em estudarmos o TCA nos pacientes com mecanismo IgE mediado, já que na literatura este teste têm sido avaliado em pacientes com asma, rinite e dermatite atópica utilizando aeroalérgenos (Guler et al, 2006; Holm et al, 2004).

$\mathrm{Na}$ descrição da nossa casuística, foram incluidos pacientes com manifestações clínicas IgE mediadas com o objetivo de avaliar os resultados do TCA e o possível aprimoramento do diagnóstico de APLV. Neste grupo de pacientes, quase metade apresentavam DA e todos estes tiveram o TCA positivo. Os pacientes sem DA também apresentaram alta frequência de positividade do TCA. Na realidade, os pacientes com APLV preenchiam o critério para reações lgE mediadas pelas características das manifestações clínicas e testes diagnósticos como o TPODCPC positivo em todos deste grupo. Estes pacientes apresentaram maior frequência de positividade do TCA tanto nas 48 horas quanto nas 72 horas comparado com as 24 horas. 
Este fato aponta que apesar de serem caracterizadas como lgE mediadas, comportaram-se como pacientes com mecanismos mistos em relação ao resultado do TCA.

Um fato bastante discutido na literatura é a relação entre a positividade do TCA e a presença de lesões cutâneas. Na presente casuística foi evidenciado que a presença de lesões cutâneas não foi imprescindível para a positividade do TCA. Esta evidência também foi demonstrada com o leite de vaca em estudo com 37 crianças com suspeita de APLV, sendo que 31 crianças foram submetidas ao TPODCPC e 17 apresentaram reação imediata e quatro delas, tardia. Estas crianças realizaram o TCA e 18 deles apresentaram positividade neste teste, além de elevada IgE específica para o leite de vaca. Isto sugere que o TCA pode ser usado em crianças com manifestações alérgicas além da dermatite atópica (Keskin et al, 2005).

Os primeiros estudos com TCA foram em pacientes com dermatite atópica e por conta disto, acreditava-se que o TCA seria positivo somente em pacientes com lesões cutâneas, já que estes pacientes possuem maior reatividade e alteração da permeabilidade da pele. Aqueles pacientes que não apresentavam eczema seriam não responsivos (Beltrani e Hanifin, 2002). Esta hipótese, suportada por outros autores ainda é aceita, provavelmente, pela escassez de estudos em pacientes sem lesões cutâneas. Entretanto, alguns estudos com grupos controles ou pacientes atópicos sem dermatite atópica, mostrou resultados de TCA com aeroalérgenos positivos (Ingordo et al, 2004; Seidenari et al, 2003).

$\mathrm{Na}$ literatura, um estudo que avaliou pacientes com asma ou rinite, que apresentavam prick test positivo e aumento de $\lg E$ sérica específica para Dermatophagoides pteronyssinus, o TCA foi positivo apenas em $25 \%$ (Holm et al, 2004). Uma explicação para este achado é a hipótese que as células de Langerhans com expressão de $\operatorname{lgE}$ são mais eficientes em capturar e apresentar o alérgeno para células $T$ alérgeno específicas do que pelas células de Langerhans sem esta imunoglobulina (Mudde et al, 1990). Provavelmente, a resposta cutânea do TCA é dependente desta variável, 
podendo haver resposta IgE sérica específica não acompanhada de uma resposta cutânea (Holm et al, 2004).

Em relação ao grupo controle, optamos pela escolha de um grupo que buscou o serviço com hipótese de APLV, entretanto este diagnóstico foi excluído após avaliação clínica e laboratorial. Este grupo foi composto por 9 pacientes, pela dificuldade de comparecimento ao Hospital, o que dependeu apenas da vontade de participação do estudo, mesmo sem nenhum benefício. Além disso, para a realização do TCA estes pacientes foram submetidos a retornos múltiplos. Mesmo com estas dificuldades achamos fundamental a inclusão deste grupo, fato este pouco descrito nos estudos publicados sobre o tema.

Foi fundamental a inclusão de pacientes com DETD desencadeada através de mecanismos mistos, uma vez que o envolvimento de linfócitos é concomitante à doença e ao mecanismo do TCA. Neste contexto faz-se importante a realização deste teste como um instrumento adicional ao diagnóstico de AA nesses pacientes.

Um dos aspectos iniciais a ser avaliado foi a característica dos pacientes que compuseram esta casuística. Nos pacientes com APLV IgE mediada houve predomínio de quadros cutâneos assim como é relatado na literatura (Benhamou et al, 2009). Neste grupo sete pacientes apresentavam dermatite atópica.

$\mathrm{Na}$ avaliação dos nossos pacientes com DETG observamos que o maior número de sintomas relatados foram aqueles que mimetizavam a DRGE, como vômitos, dor abdominal e epigastralgia, seguindo a percepção de estudos anteriores sobre EoE (Erwin et al, 2010; Liacouras et al, 2005). Assa'ad et al (2007) em avaliação de pacientes pediátricos num período de oito anos, observaram que o vômito era o achado mais importante em todas as idades avaliadas, estando a disfagia e impactação presentes em idades mais avançadas. Um estudo realizado com mais de 600 crianças e 1000 pais sobre a percepção de sintomas relacionados à DRGE, como epigastralgia, dor abdominal, vômitos, recusa alimentar e dor torácica, encontrou alta prevalência desses relatos na infância, tanto dos pais de 
crianças menores, quanto na percepção das próprias crianças, quando eram maiores que dez anos (Nelson et al., 2000). Podemos entender que a alta prevalência da DRGE na infância, com sintomas semelhantes aos da EoE, pode levar muitos médicos e especialistas à confusão diagnóstica. A impactação é um sintoma observado mais em adultos, os quais podem ser assintomáticos e apresentarem súbito quadro de disfagia (Straumann et al., 2001). Esse sintoma foi relatado em um número menor de pacientes deste estudo e com idade média mais elevada, provavelmente pelo acometimento progressivo da mucosa esofágica, levando a fibrose subepitelial, espessamento e diminuição do calibre esofágico, que dificultam a passagem do alimento (Li-Kim-Moy et al, 2011).

A associação com outras doenças alérgicas é comum entre os pacientes com alergia alimentar, como o observado neste estudo. Estudos que envolveram a realização de TPODCPC para diagnóstico de alergia alimentar em pacientes com DA estimaram uma associação em $30 \%$ dos casos (Sampson e Sicherer, 1999). Sabe-se que sintomas respiratórios isolados relacionados à alergia alimentar não são muito comuns (James, 2003), no entanto quando são relatados em associação com envolvimento de outros sistemas conferem maior gravidade ao processo alérgico, em especial a asma (Clark e Ewan, 2003).

Os pacientes portadores de DETG do presente estudo, semelhante ao observado na literatura mundial, apresentaram alta associação com doenças alérgicas. Liacouras et al (2005), em avaliação de 381 crianças por um período de dez anos, relataram evidência de outras condições alérgicas como Asma, Rinite Alérgica e DA em 53\% deles. Entre as doenças alérgicas associadas à EoE, a AA é bem documentada na literatura mundial (Spergel et al, 2007; Chehade e Aceves, 2010).

A presença de antecedentes familiares de atopia, bastante freqüente entre os pacientes deste estudo, é uma característica comum em pacientes alérgicos e constitui um aspecto complementar importante, quando se realiza a anamnese de pacientes com alergia alimentar (Sampson, 2004; Kumar, 2008). Relatos de EoE em indivíduos da mesma família já foram 
descritos por Patel et al (2005), bem como casos entre irmãos e entre pais e filhos, sugerindo a possibilidade de a EoE, como as doenças atópicas, apresentar uma predisposição genética (Blanchard et al,2006).

$\mathrm{Na}$ presente casuística, a pesquisa de IgE específica, seja por prick test ou in vitro através do ImmunoCAP mostraram maior freqüência de positividade nos pacientes com APLV IgE mediada, quando comparado com o grupo controle e com os pacientes com doenças eosinofílicas do trato gastrintestinal. Isto se deve ao fato que embora este último grupo de pacientes classicamente apresentem mecanismo imunológico misto, em alguns indivíduos a contribuição da $\lg E$ pode ser menos significativa, ressaltando ainda mais a necessidade de realização do TCA.

O TCA tem sido citado como um método diagnóstico adicional na alergia alimentar. Entretanto, a literatura apresenta resultados discrepantes quanto à padronização, principalmente em relação ao tipo e à concentração dos alérgenos. No início deste estudo, também encontramos dificuldade para definir qual seria a concentração ideal do alérgeno para ser utilizada nos pacientes desta casuística. Optamos por testar o extrato de leite de vaca a $20 \%$, cedido pela IPI ASAC Espanha, e o leite de vaca in natura. A razão pela escolha destes alérgenos foi justificada pelo fato de que a concentração de $20 \%$ de proteína do alimento também tem sido descrita na literatura e o leite in natura seria uma opção de fácil acessibilidade (Canani et al, 2007).

A maioria dos estudos publicados utilizou os alérgenos mais comuns na infância como leite de vaca, ovo, trigo, soja (Isolauri e Turjanmaa, 1996; Vanto et al,1999; Majamaa et al, 1999; Hansen et al, 2004). O alimento escolhido para este estudo foi o leite de vaca, não só pelo fato de ser um alérgeno importante, mas também por ser aquele associado as doenças eosinofílicas em crianças de baixa idade no ambulatório da Unidade.

A preparação de alérgenos utilizada para o TCA com alimentos ainda não está padronizado e a diferença na preparação dos materiais é responsável pelos resultados controversos na literatura. A maioria dos autores utiliza o leite in natura contendo $3,5 \%$ de proteína, entretanto a concentração do alérgeno não é conhecida. Há poucas padronizações de 
extratos comerciais de alimentos preparados, entre eles, existe o Diallertest e E-patch ${ }^{\circledR}$ para leite de vaca (Kallach et al,2005), Rapid patch set ${ }^{\circledR}$ para 10 alimentos (Soury et al, 2005). A vantagem em usar o alimento in natura é que este pode ser utilizado em outros testes como o prick teste e nas provocações e o resultado destes 3 exames podem ser melhor comparados (Niggemann, 2002). Na literatura encontramos um estudo em que comparou estas duas formas de apresentação do leite e obteve melhores resultados com o leite in natura (Canani et al, 2007). Esta diferença pode ser causada por vários fatores, ente eles: a purificação do extrato, a concentração do antígeno e a capacidade de penetração na pele.

$\mathrm{Na}$ literatura européia, os alérgenos in natura são os preferidos. $\mathrm{O}$ leite de vaca, a fórmula de soja e o ovo são colocados diretamente sobre o papel de filtro, enquanto o trigo e os outros farináceos sofrem reconstituição com veículo aquoso (Isolauri e Turjanmaa, 1996). Na literatura americana os trabalhos realizados em pacientes com EoE utilizam uma concentração de 2 gramas do produto em pó (leite desnatado, extrato de soja, farinha de trigo, ovo liofilizado) com $2 \mathrm{ml}$ de soro fisiológico, tornando o resultado final uma pasta de maior concentração proteica que é colocada diretamente sobre a placa de alumínio (Spergel et al, 2002).

No presente estudo, foi utilizado o leite de vaca in natura sobre o papel de filtro e o extrato comercial de leite de vaca $20 \%$ diluído em petrolato.

A experiência obtida em nosso estudo com este alimento foi interessante e satisfatória, mostrando que o extrato de leite a $20 \%$ e o leite in natura foram semelhantes em relação à positividade do teste. Para a utilização rotineira na prática clínica, acreditamos que o leite in natura é suficiente para a execução do TCA. O único cuidado a ser tomado é em relação ao posicionamento da câmara com o leite in natura. O ideal é não colocá-lo na porção superior da coluna de extratos, já que pode escorrer sobre as outras substâncias, fato observado neste estudo quando realizamos um estudo piloto avaliando alguns testes. Neste momento, o primeiro material colocado na câmara de plástico foi o leite in natura, 
entretanto, observamos que em alguns testes, mesmo usando o papel de filtro, o leite escorreu sobre as outras câmaras contaminando o extrato de leite de vaca a $20 \%$. Estes testes foram desconsiderados. Após este fato, nos testes subseqüentes, padronizamos que na primeira câmara seria colocado o controle negativo de petrolato, seguido pelo extrato de leite de vaca a $20 \%$ e posteriormente o leite de vaca in natura, para que não ocorresse o fato anteriormente descrito.

O uso de petrolato (vaselina) como veículo parece ser vantajoso em relação às soluções aquosas (Darsow et al, 1995). Entretanto, ambos os veículos resultaram no mesmo número de testes positivos, sem diferenças histológicas. Aqueles que utilizaram o petrolato apresentaram reações mais intensas comparados aos que utilizaram o veículo aquoso (Oldhoff et al, 2004). O petrolato também é usado como controle negativo em outros estudos (Rancé,2004; Holm et al, 2004; Darsow et al, 2004, Keskin et al, 2005). Na literatura também é citado o uso da solução salina como controle negativo, sem reações adversas (Canani et al, 2007). No presente estudo utilizamos o petrolato como veículo, que quando testado isoladamente não apresentou nenhuma reação adversa e tem a vantagem de não escorrer para fora da câmara de plástico, o que ocorre com as soluções aquosas.

Neste estudo utilizamos as câmaras de $12 \mathrm{~mm}$, assim como é descrito na literatura (Niggeman et al, 2000; Darsow et al, 2004; Rancé, 2004; Canani et al, 2007). O material cedido pela (IPI ASAC- Brasil) foram as câmaras de plástico, composta por material de polietileno, sendo esta também utilizada por Ronchetti et al, 2008. Há uma série de estudos na literatura que descrevem o uso das Finn Chambers de alumínio (Niggeman et al, 2000; Isolauri e Turnjamaa,1996, Spergel et al, 2002). Embora na literatura haja uma preferência pela câmara de alumínio, a utilização da câmara de plástico foi adequada neste estudo. Não observamos nenhuma reação cutânea no local de contato com a pele e nenhum pacientes reclamou sobre a adaptação desta na pele.

Na literatura, a maioria dos autores preconizam um tempo de oclusão de 48 horas, com uma leitura às 48 e 72 horas (Niggemann et al, 2000; 
Keskin et al, 2005; Darsow et al, 2004; Spergel et al, 2005). Em relação à escolha do tempo de leitura, à semelhança da metodologia de Rancé, 2004, utilizamos três tempos de leitura de 24,48 e 72 horas. O tempo de leitura de 24 horas foi escolhido pela inclusão de um grupo de APLV IgE mediada, que poderia mostrar uma positividade do TCA nas 24 horas (Rancé, 2004; Darsow et al, 2004). Além disso, o grupo com doenças eosinofílicas do trato digestório, por apresentar doença com o envolvimento de mecanismos celulares e da IgE, também poderia mostrar uma positividade mais precoce do teste. Entretanto, em ambos os grupos a frequência de positividade foi maior a partir das 48 horas de leitura.

Apesar da análise estatística mostrar semelhança entre os tempos de leitura de 48 e 72 horas, como conduta escolhemos a leitura de 72 horas. A justificativa para esta escolha é sua semelhança da leitura do teste de contato utilizado para o diagnóstico da dermatite de contato e além disso há a possibilidade que nas primeiras 48 horas o teste possa ser positivo pela irritação causada pelo alérgeno e não pela reação verdadeiramente causada pela resposta tardia ao alérgeno, já aventada pela Sociedade de Dermatologia em relação ao teste de contato feito com haptenos.

Os pacientes com APLV apresentaram um comportamento diferente quando utilizado o leite in natura, mostrando semelhança entre todos os tempos de leitura. Uma possível explicação para isto é que diferente dos pacientes com DETD, os pacientes com APLV IgE mediada também apresentaram resposta na leitura de 24 horas, compatível com os mecanismos imunológicos envolvidos na fisiopatologia da doença. $O$ fato desta observação não ocorrer com o extrato de leite a $20 \%$ permanece a ser esclarecido.

Durante o agendamento dos pacientes para a realização do teste, foram importantes as recomendações para a interrupção do uso de medicamentos como os glicocorticóides orais e tópicos, pois podem alterar o influxo de células inflamatórias prejudicando o teste (Langeveld- Wildschut et al, 2000). Alguns autores recomendam a exclusão dos antiinflamatórios sistêmicos e tópicos 72 horas antes do teste (Heine et al, 2006) e outros 7 
dias antes do teste (Rancé, 2004, Ronchetti et al, 2008). Em relação aos corticóides inalados ou deglutidos, solicitamos a exclusão 15 dias antes do teste. No artigo de Ronchetti et al (2008) esta conduta já era adotada. Condição semelhante também foi sugerida com 0 uso dos imunomoduladores tópicos como o Pimecrolimus e 0 Tacrolimus (Weissenbacher et al, 2006). Até o momento não há evidências sobre o uso de anti-histamínicos orais e a realização dos TCA, e embora não tenha correlação com os mecanismos da patogênese do teste, a medicação pode reduzir o eritema, sendo por isto recomendada sua suspensão pelo menos 72 horas antes da aplicação do teste (Turjanmaa et al, 2006). Neste estudo, foi orientado a exclusão do uso de anti-histamínicos 7 dias antes do teste, pois os pacientes retornaram para uma leitura precoce após 24 horas de oclusão. De acordo com relato na literatura, após biópsias realizadas no local do TCA, foi constatado que nas primeiras 48 horas há predomínio de células TH2 e após as 48 horas predomina as células TH1 (Van Reijsen et al, 1992). Com isto, para evitar falsos negativos, recomendamos a exclusão de anti-histamínicos orais 7 dias antes do teste (Ronchetti et al, 2008).

No presente estudo, percebemos a importância dessas orientações e idealizamos um check list incluindo um contato por telefone com o paciente na véspera do teste para reforçar estas recomendações. Com todos estes cuidados foi possível realizar a aplicação do teste em todos os pacientes, sem necessidade de cancelamento do exame.

Desde o início do agendamento, os responsáveis estavam cientes da necessidade de comparecimento do paciente no Hospital das ClínicasInstituto da Criança quatro dias seguidos (um dia para a aplicação, e três dias para as seguintes leituras de $24,48,72$ horas), por isto o teste foi agendado às segundas-feiras e marcado conforme a disponibilidade dos pais ou responsáveis e da agenda escolar da criança.

Com relação às reações adversas, pode haver reações locais como prurido e dermatite de contato local (Stromberg, 2002; Niggemann et al, 2000). Em pacientes com quadros IgE mediados podem se associar urticária, rinoconjuntivite, asma. Também foram descritas exacerbações da 
dermatite atópica com aumento das lesões flexurais e/ou face após a aplicação dos TCA (Darsow et al, 2004). Há um relato de que 2 pacientes de um total de 37 pacientes com APLV que foram submetidos ao teste, apresentaram vermelhidão e prurido no local da Finn Chamber após 1 semana (Keskin et al,2005). Há estudos na literatura onde não foi encontrada reações adversas ao teste (Rancé, 2004). Portanto, o TCA é um teste que provoca poucas reações adversas.

Em relação aos achados no nosso estudo, observou-se a presença de dermatite irritativa pelo adesivo em um caso e prurido local em quatro casos. As reações adversas encontradas neste estudo foram semelhantes às descritas na literatura. Podemos perceber que este teste é seguro e isento de reações graves, podendo ser realizado em consultórios e ambulatórios por profissional treinado.

Alguns autores sugerem para os pacientes com DETD, uma dieta de exclusão de vários alimentos ou o uso de dietas elementares, com posterior realização de endoscopia e colonoscopia e biópsias seriadas após introdução de cada alimento suspeito (Kagalwalla et al, 2006; Markowitz et al, 2003). Essa prática pode ser difícil para muitos centros médicos no Brasil, pela dificuldade em realizar exames de EDA e colonoscopia com biópsia e pela pobre adesão às dietas de restrição por parte de alguns pacientes.

Pacientes com gastroenterite eosinofílica apresentam menor sensibilização à alimentos comparados aos pacientes com EoE (Assa'ad, 2009).

Em relação ao uso do TCA na esofagite eosinofílica, um dos primeiros estudos mostrando a associação de alergia alimentar e EoE foi demonstrado por Kelly et al em 1995. Este grupo avaliou 10 pacientes pediátricos com sintomas que não respondiam ao tratamento habitual para a doença do refluxo gastroesofágico e com alteração histológica como hiperplasia epitelial e infiltração eosinofílica no esôfago. Todos os pacientes foram tratados com terapia antirefluxo sem resolução dos sintomas clínicos e endoscópicos. Os autores suspeitaram que os sintomas clínicos e as alterações histológicas fossem causados por uma reação de hipersensibilidade a proteínas da dieta. 
Os pacientes receberam uma dieta de substituição das proteínas por fórmula de aminoácidos por 6 semanas, sendo que 6 pacientes apresentaram normalização endoscópica. Houve uma redução significativa no número de eosinófilos em 10 pacientes e uma completa resolução em 5 pacientes. Estes pacientes foram submetidos a uma provocação oral aberta. A reintrodução dos alimentos reproduziu os sintomas em 9 dos 10 pacientes, com média de uma hora após a introdução dos alimentos. Os principais alimentos foram leite de vaca em sete pacientes, a soja em quatro pacientes, o trigo em dois pacientes, o amendoim em dois pacientes e o ovo em um paciente. Os autores concluíram que pacientes com diagnóstico de doença do refluxo gastroesofágico, com eosinofilia no esôfago e falha com o tratamento convencional, deve ser considerado como uma EoE associada à hipersensibilidade alimentar.

A casuística aqui mencionada foi composta por 30 pacientes com doenças eosinofílicas do trato digestório, sendo que 20 destes apresentaram o TCA positivo para leite de vaca nas 72 horas. Todos estes pacientes estavam em uso de medicação específica, como budesonida deglutida em doses habituais $(800 \mathrm{mcg})$, porém sem melhora clínica expressiva. Após três meses da exclusão do leite, estes pacientes retornaram em consulta no ambulatório para reavaliação clínica e endoscópica. A melhora clínica foi constatada em dezesseis pacientes e em treze pacientes observou-se tanto melhora clínica quanto endoscópica. Nossos achados são semelhantes aos encontrados na literatura (Spergel et al, 2002). Entre os pacientes não responsivos, deve-se enfatizar que 4 deles apresentavam diagnóstico de impactação, fato este que poderia interferir na resposta do paciente ao tratamento, já que este diagnóstico é acompanhado do achado de fibrose subepitelial, espessamento da mucosa, levando à redução do calibre para passagem do alimento (Li-Kim-Moy et al, 2011)

A associação de alérgenos alimentares e EoE criou desafios sobre a identificação destes através de teste alérgicos. Spergel et al, demonstraram que o uso associado de prick teste e o teste de contato atópico ajudaram na identificação de alimentos que podem contribuir para a piora da EoE. Neste 
estudo 26 crianças com EoE realizaram o prick test e o TCA para a identificação de possíveis alimentos desencadeantes. O leite e o ovo foram os alimentos mais comumente identificados no prick teste, enquanto o trigo foi o alimento mais comumente encontrado no TCA. Os alimentos mais implicados neste estudo foram: leite de vaca, ovo, soja, amendoim, e trigo. Os autores concluiram que a dieta de eliminação destes alérgenos resultou na resolução dos sintomas em 18 pacientes e uma melhora parcial em 6 pacientes. Dois pacientes perderam o seguimento ao longo do estudo. $\mathrm{Na}$ biópsia foi demonstrado que a contagem de eosinófilos no esôfago decresceu de 55.8 para 8.4 eosinófilos por campo de grande aumento após a dieta.

Este estudo é muito semelhante a esta dissertação aqui descrita, pois apresenta casuística e metodologia semelhante. Vale ressaltar que os autores deste estudo comentado utilizaram vários alimentos para realização do TCA alcançando alta positividade da associação de alimentos na EoE. Nosso estudo, ao contrário, utilizou apenas o leite e mesmo assim alcançou $66,6 \%$ de positividade de um total de 30 pacientes com DETD. Destes, o TCA contribuiu para a melhora clínica em cerca da metade dos pacientes e na melhora tanto clínica como histológica em cerca de $40 \%$ dos pacientes. Assim, a contribuição do TCA poderia ser mais robusta se outros alimentos também fossem pesquisados.

É importante ressaltar que se não fosse possível a realização do TCA nos pacientes com DETD, provavelmente o próximo passo na conduta seria a realização da exclusão de vários alimentos e até a introdução de uma fórmula elementar de leite, podendo acarretar restrições dietéticas importantes, interferindo na qualidade de vida destas crianças e adolescentes.

Durante a pesquisa, constatamos uma limitação importante do estudo, que é o fato de não sabermos qual a taxa de resolução espontânea da DETD, em especial da EoE, que poderia interferir nos resultados aqui apresentados. 
Como conclusão, esta dissertação abriu uma nova linha de pesquisa em alergia alimentar e com certeza o uso do TCA nos pacientes com doença de mecanismo misto, celular ou IgE mediado pode ser de valia para auxílio na conduta do tratamento dietético destes pacientes.

Os resultados aqui mencionados, mostram que o TCA pode ser reproduzido com material de fácil acessibilidade, é seguro e nos tempos de oclusão e leitura aqui preconizados podem auxiliar no tratamento de pacientes com DETD que não estavam responsivos à terapêutica instituída. Com certeza, é só o início de um longo caminho. 
Conclusões 


\section{CONCLUSÕES}

1. O TCA com ambas as preparações de leite de vaca mostrou-se útil na identificação do leite como alimento desencadeante em especial no grupo das DETD, já que nos pacientes com APLV existe métodos adicionais para este fim.

2. Ambas as preparações utilizadas no TCA, neste estudo, apresentaram desempenho semelhante, optando-se pelo leite in natura pela sua acessibilidade para uso na prática clínica diária.

3. Em relação aos diferentes tempos de leitura, avaliando-se a positividade do TCA nos tempos de 48 e 72 horas, os resultados foram semelhantes optando-se pela leitura de 72 horas para exclusão da possibilidade de reação irritativa na leitura de 48 horas.

4. Na avaliação dos pacientes com DETD, o TCA foi útil na identificação do leite como alimento desencadeante dos sintomas e na instituição da dieta de restrição, contribuindo para a melhora clínica e histológica em um número representativo de pacientes. 
Anexos 
Anexo A - Aprovação do estudo pela Comissão de Ética para análise de Projetos de Pesquisa da Diretoria Clínica do Hospital das Clínicas

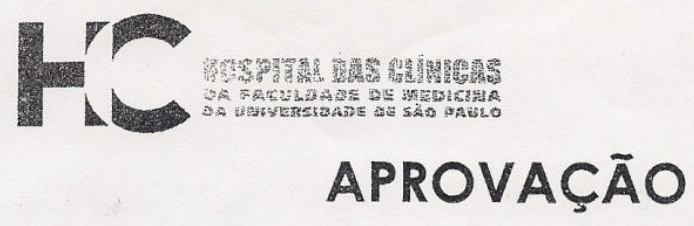

A Comissão de Ética para Análise de Projetos de Pesquisa - CAPPesa da Diretoria Clínica do Hospital das Clínicas e da Faculdade de Medicina da Universidade de São Paulo, em sessāo de 14/11/2007, APROVOU O Protocolo de Pesquisa n 0995/07, intitulado: "PADRONIZAÇĀO DO PATCH TEST PARA O DIAGNÓSTICO DE ALERGIA ÀS PROTEÍNAS DO LEITE DE VACA " apresentado pelo Departamento de PEDIATRIA, inclusive $\circ$ Termo de Consentimento Livre e Esclarecido.

$$
\text { Cabe ao pesquisador elaborar e apresentar à }
$$
CAPPesq, os relatórios parciais e final sobre a pesquisa (Resoluçāo do Conselho Nacional de Saúde n 196, de 10/10/1996, inciso IX.2, letra "c").

Pesquisador (a) Responsável: Cristina Miuki Abe Jacob Pesquisador (a) Executante: Flavia Rabelo Frayha de Souza

CAPPesq, 22 de Novembro de 2007
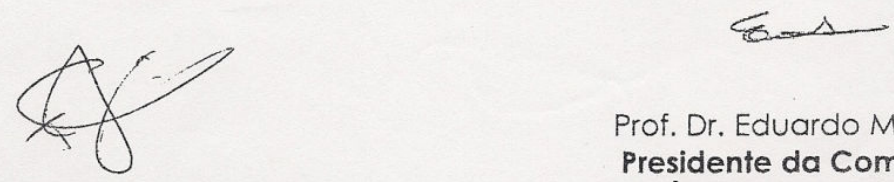

Prof. Dr. Eduardo Massad Presidente da Comissão de Ética para Análise de $64610 x$ Projetos de Pesquisa

Comissão de Ética para Anàlise de Projetos de Pesquisa do HCFMUSP e da FMUSP Diretoria Clinica do Hospital das Clinicas da Faculdade de Medicina da Universidade de São Paulo Rua Ovidio Pires de Campos, 255, $5^{\circ}$ andar - CEP 05403010 - São Paulo - SP Fone: 0113069 6442 Fax: 01130696492 e-mail: cappesq@hcnetusp.br/secretariacappesq2@henet.usp.br-sol

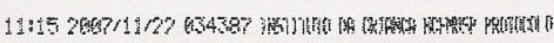

Em Outubro de 2011 houve submissão à CAPPesq da mudança do título da tese para: “ Avaliação do teste de contato atópico na alergia ao leite de vaca IgE mediada e nas doenças eosinofílicas do trato digestório". 


\section{Anexo B- Protocolo Padronizado para o Teste de Contato Atópico (página 1) \\ Unidade de Alergia e Imunologia do ICR HC FMUSP \\ Teste de Contato Atópico}

\begin{tabular}{ll} 
Nome: & idade atual : \\
Data: & RH: \\
Encaminhado por: & Tel: \\
\hline
\end{tabular}

\section{MANIFESTAÇÕES CLÍNICAS DA ALERGIA ALIMENTAR}

Idade do primeiro sintoma:_ Idade Diagnóstico:

Aleitamento Materno:____ Alimento suspeito:

Quantidade que provocou a reação:

Forma de preparo:

Intervalo de tempo desde a última reação:

Intervalo de tempo entre a ingestão do alimento e o aparecimento dos sintomas:

Tratamento recebido:

Manifestações Dermatológicas: $\square$ Eritema $\square$ Urticária $\square$ Angioedema

\begin{tabular}{|c|c|c|c|}
\hline \multirow{3}{*}{ Gastro-Intestinais: } & Prurido & Eczema $\square A O$ & \\
\hline & $\square$ Vômitos & $\square$ Diarréia & $\square$ Dor Abdomina \\
\hline & Náusea & $\square$ Flatulência & $\square$ Enterorragia \\
\hline
\end{tabular}

Respiratórias:

Aftas

Prurido/Dor Em Orofaringe

$\square$ Chiado $\quad \square$ Estridor $\quad \square$ Tosse

Dificuldade Respiratória $\quad \square$ Prurido

Espirros $\quad \square$ Obstrução Nasal $\quad \square$ Coriza

Conjuntivite $\quad \square$ Lacrimejamento

Manifestações Sistêmicas:

口Hipotensão $\square$ Cefaléia $\square$ Desmaios

\section{ESOFAGITE EOSINOFÍLICA}

\section{$\underline{\text { CLÍNICA }}$}

Cólica do lactente $\square$

DRGE Sim $\square$ Não $\square$ Idade:_ EED $\_$EDA $\square$ pH metria $\square$ Tratamento Impactação com alimentos $\square$

Dor abdominal $\square \quad$ Baixo ganho pondero estatural $\square$

Dor epigástrica $\square \quad$ Disfagia $\square$

Vômitos $\square \quad$ Alimentação lenta

COM

CONTAGEM

DE

EOSINÓFILOS:

TRATAMENTO ANTERIOR/ DURAÇÃO:

TRATAMENTO ATUAL/DURAÇÃO: 
Anexo B - Protocolo Padronizado para o Teste de Contato Atópico (página 2)

Unidade de Alergia e Imunologia do ICR HC FMUSP

\begin{tabular}{|c|}
\hline DIAGNÓSTICOS SECUNDÁRIOS \\
\hline$\square$ Asma $\square$ Rinite $\square$ DA $\square$ Alergia outros alimentos $\square$ Gastroenteropatia eosinofílica \\
\hline
\end{tabular}

\section{MEDICAMENTOS}

Medicamentos utilizados nas últimas 24 horas:

Medicamentos utilizados nos últimos 10 dias:

Medicamentos utilizados nos últimos 30 dias:

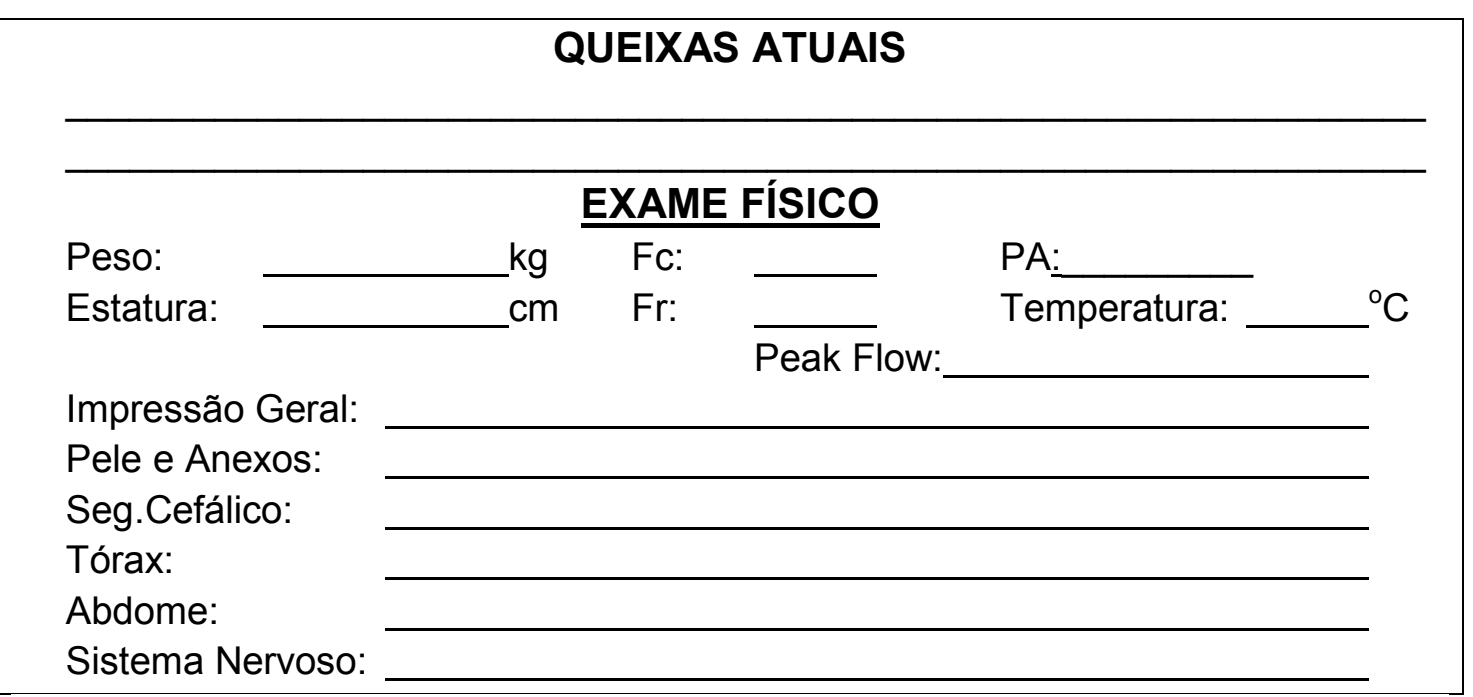


Anexo C- Impresso com o resultado do Teste de Contato Atópico

Unidade de Alergia e Imunologia do ICR HC FMUSP

Nome:

Teste de Contato Atópico

Idade:

Data do exame:

Diagnóstico:

\section{Evolução do Teste}

\begin{tabular}{|l|l|l|l|}
\hline \multicolumn{5}{c|}{ Resultados } \\
\hline 1. Vaselina & & & \\
\hline 2. Leite de vaca 20\% & & & \\
\hline 3. Leite de Vaca in natura & & & \\
\hline
\end{tabular}

Interpretação
A)Negativo Reação ausente
B)Duvidoso Leve Eritema
C)Positivo + Eritema e Infiltração
D)Positivo++Eritema, edema, pápulas
E)Positivo +++ Eritema e vesículas

\section{Intercorrências}

$\square$ Abertura do teste pelo paciente

$\square$ Descolamento espontâneo do micropore

$\square$ Uso de medicação proibida durante o teste

$\square$ Traumatismo no local do teste por coçadura

$\square$ Umedecimento do local

$\square$ Exposição ao sol do local do teste

$\underline{\text { RESULTADO DO TESTE }}=\square$ Positivo $\square$ Negativo $\square$ Duvidoso 
Anexo D- Orientações para a realização do Teste de Contato Atópico

Unidade de Alergia e Imunologia do Departamento de Pediatria da FMUSP

\section{pré teste}

\section{Orientações}

1- Manter dieta sem leite de vaca. Observar atentamente os rótulos dos alimentos

2- $\quad$ Evitar os seguintes medicamentos:

Anti-alérgicos ( 7 dias antes do exame)

Corticóides via oral e inalatória (15 dias antes do exame)

Imunossupressores tópicos locais (7dias antes do exame)

3- Nos dias do teste o paciente tomará banho da cintura para baixo e não poderá praticar esportes para evitar o descolamento do teste.

4- Datas do exame: Aplicação:

Retorno em 24 horas:

Retorno em 48 horas: Retorno em 72 horas:

5- $\quad$ Horário: 9: $00 \mathrm{~h}$ na sala de vacina (Próximo ao SAME)

6- O paciente deverá estar acompanhado por responsável maior que 18 anos de idade

7- Duração aproximada do exame: 2 horas

9- Confirmaremos o exame 1 dia antes (médica responsável)

Dra Flavia Frayha - Telefone: (13) 78053523 
Anexo E- Orientações durante e após a realização do Teste de Contato Atópico

\section{Unidade de Alergia e Imunologia do Departamento de Pediatria da} FMUSP

\section{Orientações}

1- Manter dieta sem leite de vaca. Observar atentamente os rótulos dos alimentos

2- $\quad$ Anotar todos os sintomas que surgirem nos dias seguintes ao teste. Se necessário, retornar ao Hospital.

3- $\quad$ Anotar medicamentos utilizados

4- Lembrar:

- Os esparadrapos não poderão ser molhados ou retirados.

- Poderá ter coçeira no local, mas o teste não pode ser tirado.

- Evitar exercícios físicos como natação, educação física nos dias do teste

5- Retornar para consulta médica dia: 


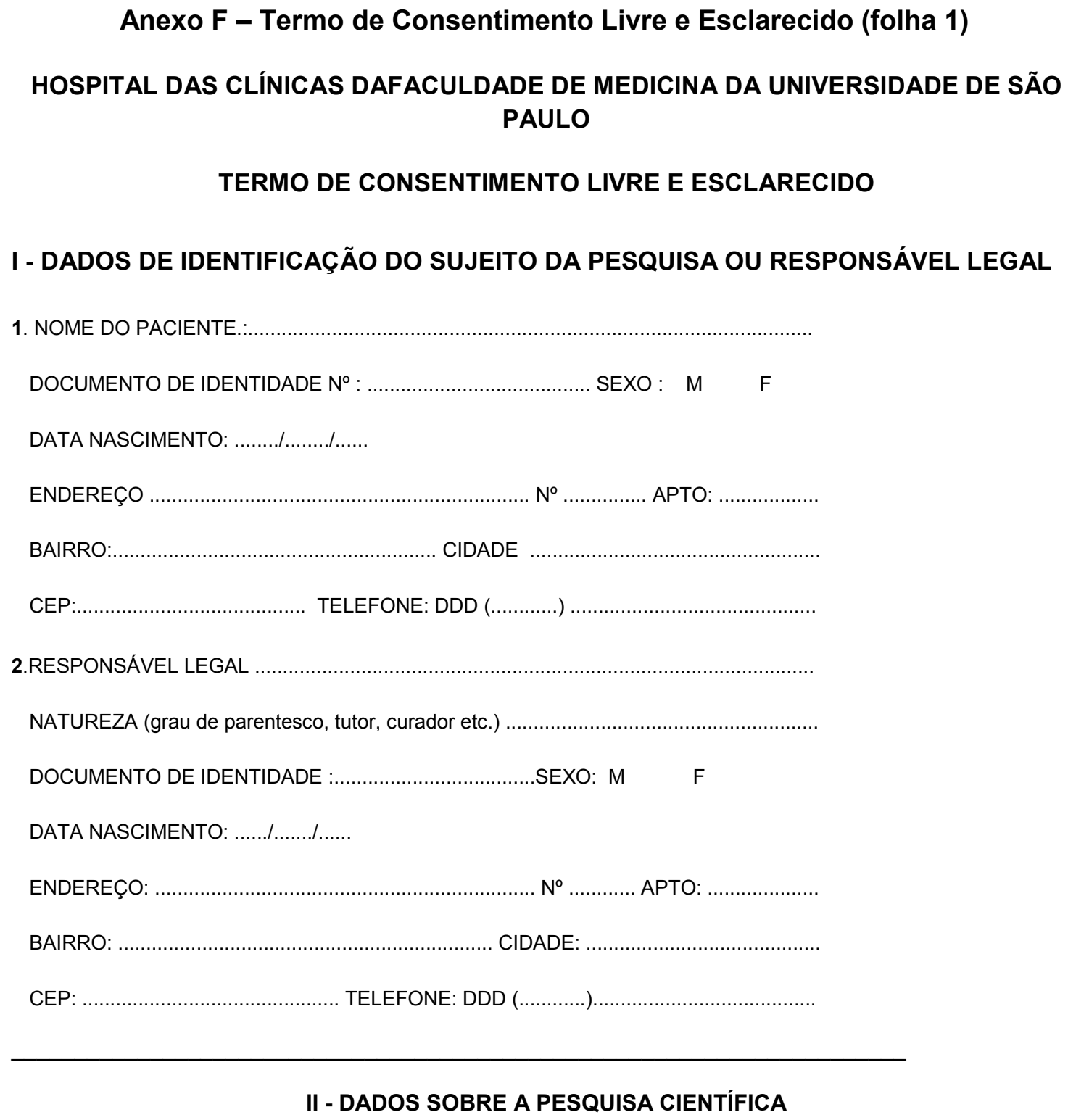

\section{II - DADOS SOBRE A PESQUISA CIENTÍFICA}

1. TÍTULO DO PROTOCOLO DE PESQUISA : AVALIAÇÃO DO TESTE DE CONTATO ATÓPICO NA ALERGIA AO LEITE DE VACA IgE MEDIADA E NAS DOENÇAS EOSINOFÍLICAS DO TRATO DIGESTÓRIO

PESQUISADORA: Cristina M Abe Jacob

CARGO/FUNÇÃO: CHEFE DA UNIDADE DE ALERGIA E IMUNOLOGIA DO ICR - HCFMUSP INSCRIÇÃO CONSELHO REGIONAL NNo 36304

UNIDADE DO HCFMUSP: UNIDADE DE ALERGIA E IMUNOLOGIA DO ICR HC FMUSP

3. AVALIAÇÃO DO RISCO DA PESQUISA:

SEM RISCO RISCO BAIXO

RISCO MÍNIMO $\square \mathrm{X} \quad$ RISCO MÉDIO RISCO MAIOR

(probabilidade de que o indivíduo sofra algum dano como consequência imediata ou tardia do estudo)

4. DURAÇÃO DA PESQUISA: 2 ANOS 


\section{Anexo F - Termo de Consentimento Livre e Esclarecido (folha 2)}

\section{III - REGISTRO DAS EXPLICAÇÕES DO PESQUISADOR AO PACIENTE OU SEU REPRESENTANTE LEGAL SOBRE A PESQUISA, CONSIGNANDO:}

1. Justificativa e os objetivos da pesquisa: Para confirmar o diagnóstico de alergia a leite de vaca em seu filho, estamos desenvolvendo um exame especial neste Hospital, chamado Patch Test

2. Procedimentos que serão utilizados e propósitos, incluindo a identificação dos procedimentos que são experimentais: Os pacientes com suspeita de alergia ao leite de vaca serão inicialmente examinados e farão exames de sangue e testes na pele para avaliar o grau de alergia. Após, aqueles que concordarem serão submetidos a este novo teste, chamado patch test. Para fazer o teste coloca-se um pouco de leite e suas proteínas em uma tampinha bem pequena, que é colada em um esparadrapo não alergênico e colocadas nas costas, bem firme para que não se soltem.Este esparadrapo não poderão ser molhados ou retirados. Quando a pessoa tem alergia ao leite, poderá ter coçeira no local, mas o teste não pode ser tirado. A criança deverá voltar em 24 horas (um dia após) e depois em 48 horas (dois dias após) para verificarmos se apresentou algum grau de alergia que será fotografado. A leitura final será feita com 72 horas (três dias após). A criança deverá permanecer em observação por meia hora após o fim do teste. Depois, será liberada para casa.

3. Benefícios que poderão ser obtidos: Com a padronização deste teste, os médicos podem melhorar a capacidade de fazer o diagnóstico da alergia ao leite de vaca. Não apenas o seu filho será beneficiado, mas também outros pacientes, nos quais o diagnóstico de alergia a leite é mais difícil.

\section{IV - ESCLARECIMENTOS DADOS PELO PESQUISADOR SOBRE GARANTIAS DO} SUJEITO DA PESQUISA:

1. Acesso, a qualquer tempo, às informações sobre procedimentos, riscos e benefícios relacionados à pesquisa, inclusive para dirimir eventuais dúvidas: Se seu filho participar do estudo você deverá ser informado de todos os procedimentos que ele irá fazer, será esclarecido dos riscos e benefícios e a qualquer tempo poderá pedir qualquer informação que desejar aos médicos pesquisadores.

2. Liberdade de retirar seu consentimento a qualquer momento e de deixar de participar do estudo, sem que isto traga prejuízo à continuidade da assistência: $A$ participação ou não do estudo depende de você e se decidir participar, você deverá assinar esse Termo de Consentimento. Você é livre para desistir a qualquer momento desse estudo e sem dar explicações e neste caso, o atendimento de seu filho na unidade continuará com a mesma qualidade. Afirmamos a você, que seu filho não será prejudicado de forma nenhuma, pois os pacientes têm direito ao atendimento médico de qualidade, independente da participação em pesquisas da unidade.

3. Salvaguarda da confidencialidade, sigilo e privacidade: Se você aceitar participar do estudo, todos os seus registros médicos serão armazenados em um computador, mas seu nome e do seu filho não aparecerão nos registros. Somente a equipe médica saberá quais informações estão relacionadas a você. Os resultados do estudo poderão ser publicados em literatura médica, mas a identificação dos pacientes não será revelada. 


\section{Anexo F - Termo de Consentimento Livre e Esclarecido (folha 3)}

4. Disponibilidade de assistência no HCFMUSP, por eventuais danos à saúde, decorrentes da pesquisa: Os médicos da Unidade da Alergia e Imunologia deverão atender a qualquer problema de saúde decorrente da realização do Teste de contato atópico

\section{INFORMAÇÕES DE NOMES, ENDEREÇOS E TELEFONES DOS RESPONSÁVEIS PELO ACOMPANHAMENTO DA PESQUISA, PARA CONTATO EM CASO DE INTERCORRÊNCIAS CLÍNICAS E REAÇÕES ADVERSAS.}

Os pacientes que participarem do estudo deverão ter nomes, telefones e BIP de contato com os responsáveis pelo estudo, para poder a qualquer tempo tirar dúvidas sobre qualquer sintoma que ocorra após o teste.

Ligar Para Unidade de Alergia e Imunologia - Telefone 30698585

Dra Flavia Rabelo Frayha de Souza - celular: (13) 91167506 (13) 78053523

Dra CRISTINA MIUKI ABE JACOB - Bip: 34444545 - código: 1049324

VI. OBSERVAÇÕES COMPLEMENTARES:

\section{VII - CONSENTIMENTO PÓS-ESCLARECIDO}

Declaro que, após convenientemente esclarecido pelo pesquisador e ter entendido o que me foi explicado, consinto em participar do presente Protocolo de Pesquisa

São Paulo, de de 2 
Anexo G. Concentrações séricas de lgE total e IgE específica para leite de vaca, $\alpha$ - lactoalbumina, $\beta$ - lactoglobulina e caseína em pacientes com alergia à proteína do leite de vaca IgE mediada

\begin{tabular}{|c|c|c|c|c|c|}
\hline 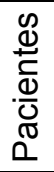 & $\begin{array}{l}\operatorname{lgE} \\
\text { Total }\end{array}$ & $\begin{array}{l}\text { Imuno } \\
\text { CAP LV }\end{array}$ & $\begin{array}{c}\text { Imuno } \\
\text { CAP } \\
\text { Alfa }\end{array}$ & $\begin{array}{c}\text { Imuno } \\
\text { CAP } \\
\text { Beta }\end{array}$ & $\begin{array}{l}\text { Imuno } \\
\text { CAP } \\
\text { Caseína }\end{array}$ \\
\hline 1 & 318 & 34,2 & 5,5 & 7,14 & 7,1 \\
\hline 2 & 2050 & 17,5 & 17,5 & 9,8 & 17,5 \\
\hline 3 & 204 & 4,11 & 2,54 & 1,98 & 3,41 \\
\hline 4 & 7440 & 75,3 & 23,1 & 7,94 & 55,8 \\
\hline 5 & 104 & 3,33 & 1,26 & 0,38 & 3,57 \\
\hline 6 & 269 & 0,59 & 0,78 & 0,59 & 0,39 \\
\hline 7 & 386 & 8,45 & 2,6 & 0,38 & 0,74 \\
\hline 8 & 18 & 0,35 & 0,35 & 0,35 & 0,35 \\
\hline 9 & 1490 & 5,89 & 0,47 & 0,47 & 2,54 \\
\hline 10 & 154 & 1,03 & 0,96 & 0,78 & 0,75 \\
\hline 11 & 663 & 10,4 & 0,35 & 2,15 & 9,8 \\
\hline 12 & 194 & 16 & 7,34 & 3,38 & 0,35 \\
\hline 13 & 102 & 0,82 & 0,52 & 0,35 & 1,08 \\
\hline 14 & 275 & 0,79 & 0,35 & 0,35 & 0,5 \\
\hline 15 & 9 & 0,35 & 0,35 & 0,35 & 0,35 \\
\hline
\end{tabular}


Anexo H. Concentrações séricas de IgE total, IgE específica para leite de vaca e frações e número de eosinófilos na biópsia esofágica ou intestinal pré e pós tratamento em pacientes com doenças eosinofílicas do trato digestório

\begin{tabular}{|c|c|c|c|c|c|c|c|}
\hline Pacientes & $\begin{array}{l}\text { IgE } \\
\text { Total }\end{array}$ & $\begin{array}{c}\text { ImunoCAP } \\
\text { LV }\end{array}$ & $\begin{array}{l}\text { Imuno } \\
\text { CAP } \\
\text { Alfa }\end{array}$ & $\begin{array}{l}\text { Imuno } \\
\text { CAP } \\
\text { Beta }\end{array}$ & $\begin{array}{c}\text { ImunoCAP } \\
\text { Caseína }\end{array}$ & $\begin{array}{l}\text { No-eosinófilos } \\
\text { Biópsia } \\
\text { Pré dieta } \\
\text { exclusão }\end{array}$ & $\begin{array}{l}\mathrm{N}^{0} \text { eosinófilos na biopsia } \\
\text { após } 3 \mathrm{~m} \text { de exclusão do LV } \\
\text { nos casos TCA positivos }\end{array}$ \\
\hline 16 & 78 & 0,35 & 0,35 & 0,35 & 0,35 & 40 & 0 \\
\hline 17 & 25 & 0,35 & 0,35 & 0,35 & 0,35 & 40 & \\
\hline 18 & 34 & 14,9 & 8,99 & 0,57 & 18,8 & 36 & 20 \\
\hline 19 & 136 & 1,87 & 2,47 & 0,57 & 18,8 & 44 & 40 \\
\hline 20 & 586 & 0,35 & 0,35 & 0,35 & 0,35 & 30 & 2 \\
\hline 21 & 1380 & 5,4 & 3,2 & 0,48 & 0,52 & 22 & 4 \\
\hline 22 & 46 & 0,55 & 0,35 & 0,35 & 0,35 & 20 & 8 \\
\hline 23 & 22 & 0,35 & 0,35 & 0,35 & 0,35 & 35 & \\
\hline 24 & 21 & 0,35 & 0,35 & 0,35 & 0,35 & 42 & \\
\hline 25 & 315 & 0,92 & 0,92 & 0,35 & 1,26 & 26 & 23 \\
\hline 26 & 600 & 0,35 & 0,35 & 0,35 & 0,35 & 20 & \\
\hline 27 & 3160 & 0,35 & 0,35 & 0,35 & 0,35 & 20 & \\
\hline 28 & 2190 & 0,38 & 0,45 & 1,26 & 1,12 & 50 & \\
\hline 29 & 169 & 0,35 & 0,35 & 0,35 & 0,35 & 50 & 21 \\
\hline 30 & 340 & 4,2 & 2,4 & 0,52 & 0,64 & 30 & \\
\hline 31 & 35,1 & 35,1 & 23,5 & 5,57 & 37,7 & 20 & \\
\hline 32 & 566 & 42,2 & 6,58 & 5,9 & 52 & 20 & \\
\hline 33 & 339 & 0,35 & 0,35 & 1,13 & 0,59 & 38 & 10 \\
\hline 34 & 865 & 0,35 & 0,35 & 0,35 & 0,35 & 30 & 0 \\
\hline 35 & 759 & 0,35 & 0,35 & 0,35 & 0,35 & 36 & 18 \\
\hline 36 & 1400 & 5,36 & 6,75 & 2 & 1,94 & 56 & 50 \\
\hline 37 & 420 & 0,35 & 0,35 & 0,35 & 0,35 & 30 & 10 \\
\hline 38 & 2015 & 0,35 & 0,35 & 0,35 & 0,35 & 25 & 6 \\
\hline 39 & 480 & 1,3 & 0,66 & 0,35 & 0,47 & 20 & 0 \\
\hline 40 & 303 & 4,2 & 2 & 0,47 & 0,51 & 20 & 1 \\
\hline 41 & 219 & 0,35 & 0,35 & 0,35 & 0,35 & 25 & \\
\hline 42 & 64 & 0,35 & 0,35 & 0,35 & 0,35 & 44 & 12 \\
\hline 43 & 6,9 & 0,35 & 0,35 & 0,35 & 0,35 & 50 & 10 \\
\hline 44 & 19 & 0,35 & 0,35 & 0,35 & 0,35 & 40 & 30 \\
\hline 45 & 27 & 0,35 & 0,35 & 0,35 & 0,35 & 40 & 12 \\
\hline
\end{tabular}


Referências 


\section{REFERÊNCIAS}

Ahlstedt S, Holmquist I, Kober A, Perborn H. Accuracy of specific IgE antibodyassays for diagnosis of cow's milk allergy. Ann Allergy Asthma Immunol. 2002:89(6 Suppl 1):21-5.

Assa'ad AH. Pediatric patients with eosinophilic esophagitis: An 8- year follow-up. J Allergy Clin Immunol. 2007:119( 3):731-738.

Assa'ad AH. Eosinophilic gastrointestinal disorders. Allergy Asthma Proc. 2009:30:17-22.

Atopic dermatitis and food hypersensitivity reactions. I Pediatr. 1998;132:132-6.Bahna SL. Unusual presentations of food allergy. Ann Allergy Asthma Immunol. 2001:86:414-420.

Beltrani V, Hanifin J. Atopic dermatitis, house dust mites, and patch testing. Am J Contact Dermat. 2002:13:80-2.

Benhamou AH, Schappi Tempia MG, Belli DC,Eignmann PA. An overview of cow's milk allergy in children. Swiss Med Wkly. 2009;139;300-7.

Blanchard C, Wang N. Stinger KF, Mishra A, Fulkenrson PC, Abonia JP, Jameson SC, Kirby C, Konikoff MR, Collins MH. Eotaxin -3 and uniquely conserved gene expression profile in eosinophilic esophagitis. J clin Invest 2006;116(2):536-547

Bock SA. Prospective appraisal of complaints of adverse to foods in children during the first 3 year of life. Pediatrics. 1987;79:683-8.

Borelli S Jr, Giusti F, Seidenari S, Drzimalla K, Simon D, Disch R, Borelli S, Bousquet J, Chanez P, Chanal I, Michel FB. Comparison between RAST and Pharmacia CAP system: A new automated specific IgE assay. J Allergy Clin Immunol. 1990;85:1039-43. 
Branum AM, Lukacs SL. Food allergy among U.S. children: Trends in prevalence and hospitalizations. NCHS data brief, no 10. Hyattsville, MD: National Center for Health Statistics; 2008.

Breneman JC, Sweeney M, Robert A. Patch tests demonstrating immune(antibody and cell- mediated) reactions to foods. Ann Allergy. 1989;62:461-9.

Burks AW, James JM, Hiegel A, Wilson G, Wheeler JG, Jones SM, Zuerlein N. Atopic dermatitis and food hypersensitivity reactions. I Pediatr. 1998:132:132-6.

Canani RB, Ruotolo S, Auricchio L, Caldore M, Porcaro F, Manguso F, Terrin G, Troncone R. Diagnostic accuracy of the atopy patch test in children with food allergy- related gastrointestinal symptoms. Allergy. 2007;62:738-43. Chatchatee P, Jarvinen K, Bardina L, Beyer K, Sampson HA. Identification of IgE and IgG-binding epitopes on as-1 caseina: differences in patients with persistent and transient cow's milk allergy. J Allergy Clin Immunol. 2001 4;107:379-83.

Chehade M, Aceves, S. Food allergy and eosinophilic esophagitis. Curr Opinion Allergy Clin Immunol, 2010; 10: 231-237.

Chehade M, Mayer L. Oral tolerance and its relation to food hypersensitivities. J Allergy Clin Immunol. 2005;115:3-12.

Clark AT, Ewan PW. Food allergy inchildhood. Arch dis Child. 2003;88:79-81. Darsow U, Vieluf D, Berger J, Busse A, Czech W, et al. Dose response study of atopy patch test in children with atopic eczema. Pediatr Astma Allergy Immunol. 1999;13:115-22.

Darsow U, Laifaoui J, Kerschenlohr K, Wollenberg A, Przybilla B, Wüthrich B. The prevalence of positive reactioms in the atopy patch test with 
aeroallergens and food allergens in subjects with atopic eczema: a European muticenter study. Allergy.2004;59:1318-25.

Darsow U, Vieluf D, Ring J, Atopy patch test wist different vehicles and allergen concentration: an approach to standardization. J Allergy Clin Immunol 1995: 95: 677-84.

Eigenmann PA, Oh Jae- Won, Beyer K. Diagnostic Testing in the evaluation of Food Allergy. Pediatr Clin North Am. 2011; 58:351-62.

Eigenmann PA, Sicherer SH, Borkoswski TA, Cohen BD, Sampson HA. Prevalence of IgE-mediated food allergy among children with atopic dermatitis. Pediatrics. 1998;101:1-8.

Erwin EA; James HR, Gutekunst HM; Russo JM, Kelleher KL, Platts-Mills TA. Serum IgE measurement and detection of food allergy in pediatric patients with eosinophilic esophagitis. Ann Allergy Asthma Immunol. 2010;104:496502.

Fiocchi A, Brozek J, Schunemann H, Bahna SL et al. World Allergy Organization (WAO) Diagnosis and Rationale for Action against Cow's Milk Allergy (DRACMA) Guidelines. Pediatr Allergy Immunol. 2010;21( Suppl.21):1-125.

Fogg MI, Brown-Whitehorn T, Pawlowski NA, Spergel JM. Atopy patch test for the diagnosis of food protein- induced enterocolitis syndrome. Pediatr Allergy Immunol. 2006;17:351-5.

Furuta GT, Liacouras CA, Collins MH, Gupta SK, Justinich C, Putnam PE, Bonis $\mathrm{P}$, Hassall E, Straumann A, Rothenberg ME; First International Gastrointestinal Eosinophil Research Symposium (FIGERS) Subcommittees. et al. Eosinophilic esophagitis in children and adults: a systematic review and consensus recommendations for diagnosis and treatment. Gastroenterology. 2007;133:1342-63. 
Garside P, Milligton O, Smith KM. The anatomy of mucosal immune responses. Ann NY Acad Sci. 2004;1029:9-15.

Gonsalves N, Policarpo-Nicolas M, Zhong Q, Rao MS, Hirano I. Histopathologic variability and endoscopic correlates in adults with eosinophilic esophagitis. Gastrointest Endosc. 2006;64:313-9.

Guidelines for the Diagnosis and Management of Food Allergy in the United States: Report of the NIAID-Sponsored Expert Panel. Boyce J et al. J Allergy Clin Immunol. 2010;126:S1-S58.)

Guler N, Kirerleri E, Tamay Z, Ones U. Atopy patch testing in children with asthma and rhinitis symptoms allergic to house dust mite. Pediatr Allergy Immunol. 2006:17:346-50.

Gushken AKF. Adaptação do teste de Provocação Oral Duplo Cego Placebo Controlado para o diagnóstico de Alergia às Proteínas do Leite de vaca mediada pela Imunoglobulina E, na faixa etária pediátrica [Dissertação]. São Paulo: Faculdade de Medicina da Universidade de São Paulo; 2009.

Hamilton RG. Laboratory test for allergy and immunodeficiency disease. In: Adkinson NF Jr, Yunginger JW, Busse WW. Adkinson: Middleton's Allergy: Principles and Practice. 6 th ed. Philadelphia: Mosby; 2003. p.611-30.

Hansen T, Host A, Bindslev- Jensen C. An evaluation of the diagnostic value of different skin tests with egg in clinically egg- Allergic children having atopic dermatitis. Pediatr Allergy Immunol. 2004;15:428-34.

Heine RG, Verstege A, Mehl A, Staden U, Rolinck- Werninghaus C, Niggemann B. Proposal for a standardized interpretation of the atopy patch test in children with atopic dermatitis and suspected food allergy. Pediatr Allergy Immunol. 2006;17:213-7.

Heinemann C, Schliemann-Willers S, Kelterer D. The atopy patch test reproducibility and comparison of different evaluation methods. Allergy 2002:57:641-5. 
Hill DJ, Hosking CS, Reyes- Benito LV. Reducing the need for food allergen challenges in young children: a comparison of in vitro with in vivo testes. Clin Exp Allergy. 2001;31:1031-5.

Hogan SP, Rothenberg ME. The eosinophil as a therapeutic target in gastrointestinal disease. Aliment Phamacial Ther. 2004;20:1231-40.

Holm L, Matusevicienne G, Scheynius A, Tengvall ML. Atopy patch test with house dust mite allergen - an IgE- mediated reaction? Allergy. 2004;59:87482.

Host A, Halken S, Jacbsen HP; Eastmam A. The natural J Allergy Clin Immmunol.1997

Host A, Halken S, Jacobsen HP; Christensen AE. Herskind AM, Plesner K. Clinical course of cow's milk protein allergy/intolerance and atopic diseases in childhood. Pediatr Allergy Immunol 2002;13(Supp 15):23-8

Ingordo V, Nogare RD, Colecchia B, D'AndriaC. Is the atopy patch test with house dust mites specific for atopic dermatitis? Dermatology. 2004:51:556-62

Isolauri E, Turjanmaa K. Combined skin prick and patch testing enhances identifications of food allergy in infants with atopic dermatitis. J Allergy Clin Immunol. 1996;97:9-15.

James J. Respiratory manifestations of food sllergy. Pediatrics. 2003:111:162530.

Jesenak M, Banovcin P, Rennerova Z, Havlicekova Z, Pohanka V, Villa MP, Ronchetti R. Reproducibility of atopy patch tests over time in the general child population. Int J Dermatol 2009;48:941-6.

Kagalwalla AF, Sentongo TA, Ritz S, Hess T, Nelson SP, Emerick KM, MelinAldana $\mathrm{H}$, Li BU: Effect of six- food elimination on clinical and histological outcomes in eosinophilic esopahagitis. Clin Gastroenterol Hepatol 2006, 4(9):1097-1102. 
Kalach N, Soulaines P, Boissieu D, Duppont C. A pilot- study of the usefulness and safety of a ready-to-use atopy patch test (Diallertest) versus a comparator( Finn Chamber) during cow`s milk allergy in children. J Allergy Clin Immunol. 2005;116:1321-6

Kelly K, Lazenby A, Rowe P, Yardley JH, Perman JA, Sampson HA. Eosinophilic esophagitis attributed to gastroesophageal reflux: improvement with an aminoacid based formula. Gastroenterology. 1995;109:1503-12.

Keskin O, Tuncer A, Adalioglu G, Sekerel B, Sackesen C, Kalayci O. Evaluation of utility of atopy patch testing, skin prick testing, and total and specific IgE assays in the diagnosis of cow's milk allergy. Ann Allergy Asthma Immunol. 2005;94: 553-60.

Khan S, Orenstein SR. Eosinophilic gastroenteritis: epidemiology,diagnosis and management. Paediatr Drugs. 2002:4:563-70.

Kumar R. Epidemiology and risk factors for the development of food allergy. Pediatr Ann.2008;37:552-8.

Lake AM, Whitington PF, Hamilton SR. Dietary protein-induced colitis in breast fed infants. J Pediatr. 1982;101:906-10.

Langeveld- Wildschut EG, Riedl H, Thepen T, Bihard IC, Bruijnznzeel PLB, Bruijnzeel- Kommen CA. Modulation of the atopy patch test reaction by topical corticosteroids. J Allergy Clin Immunol. 2000;106:737-43.

Leimgruber A, Peitrequin R, Mosimann B, Claes M, Seppey Mm Jaccard $Y$, PĖcoud A. The Pharmacia CAP System: a new Assay for specific IgE. J Allergy Clin Immunol. 1989;83:176.

Liacouras CA, Furuta GT, Hirano I, Atkins D, Attwood SE, Bonis PA, Burks AW, Chehade M, Collins MH, Dellon ES, Dohil R, Falk GW, Gonsalves N, Gupta SK, Katzka DA, Lucendo AJ, Markowitz JE, Noel RJ, Odze RD, 
Putnam PE, Richter JE, Romero Y, Ruchelli E, Sampson HA, Schoepfer A, Shaheen NJ, Sicherer SH, Spechler S, Spergel JM, Straumann A, Wershil BK, Rothenberg ME, Aceves SS. Eosinophilic esophagitis: Update consensus recommendations for children and adults. J Allergy Clin Immunol. 2011; 128:3-20.e6.

Liacouras CA, Spergel JM, Ruchelli E, Verma R, Mascarenhas M, Semeao E, Flick J, Kelly J, Brown-Whitehorn T, Mamula P, Markowitz JE. Eosinophilic esophagitis: a 10-year experience in 381 children. Clin Gastroenterol Hepatol. 2005;3:1198-206.

Liacouras CA. Eosinophilic esophagitis in children and adult. $J$ Pediatr Gastroenterol Nutr. 2003:37:26-28.

Li-Kim-Moy JP. Esophageal subepithelial fibrosis and hyalinization are features of eosinophilic Esophagitis. Journal of Pediatric Gastroenterology and Nutrition. 2011; 52:147-153.

Majamaa H, Moisio P, Holm K, Kautiainen H, Turjanmaa K. Cow's milk allergy: diagnostic accuracy of skin prick and patch tests and specific lgE. Allergy. 1999;54:346-51.

Mitchell EB, Crow J, Chapman MD, Jouhal SS, Pope FM, Platts-Mills TA. Basophils in allergen-induced patch test sites in atopic dermatitis. Lancet. 1982,1:127-30.

Nelson SP, et al. Prevalence of symptoms of gastroesophageal reflux during childhood. Arch Pediatr Adolesc Med.2000; 154: 150-154.

Niggeman B, Sielaff B, Beyer K, Binder C, Wahn U. Outcome of double-blind, placebo-controlled food challenges test in 107 children with atopic dermatitis. Clin Exp Allergy.1999:29:91-6.

Niggemann B, Beyer K. Pitfalls in double, placebo-controlled oral food challenges. Allergy. 2007;62: 729-32. 
Niggemann B, Reibel S, Wahn U. The atopy patch test - a useful tool for diagnosis of food allergy in children with atopic dermatitis. Allergy. 2000;55:281-5.

Niggemann B, Ziegert M, Reibel S. Importance of chamber size for the outcome of atopy patch testin in children with atopic dermatitis and food allergy. J Allergy Clin Immunol. 2002;110:515-6.

Noel RJ, Putnam PE, Rothenberg ME. Eosinophilic Esophagitis. N Engl J Med. 2004;351:940-1.

Novembre E, de Martino M, Vierucci A. Foods and respiratory allergy. J allergy Clin Immunol. 1988;81:1059-65.

Nowak-Wegrzny A, Assa'ad AH,Bahna SL, bock SA, Sicherer SH, Teuber SS; Adverse Reactions to Food Committee of American Academy of Allergy, Asthma \& Immunology Group report: oral food challenge testing. J Allergy Clin Immunol. 2009;123(6 Suppl);S365-83.

Nowak-Wegrzny A, Sampson HA. Adverse reactions to foods. Med Clin North Am. 2006:90:97-127.

Nowak-Wegrzny A, Sampson HA. Adverse reactions to foods. Med Clin North Am. 2006:90:97-127.

Oldhoff JM, Bihari IC, Knol EF, Bruijnzeel- Koomen CA, de Bruin- Weller MS. Atopy patch test in patients with atopic eczema/ dermatitis syndrome: comparison of petrolatum and aqueous solutions as a vehicle. Allergy. 2004;59:451-6.

Osterballe M, Andersen K, Bindslev- Jensen C. The diagnostic accuracy of the atopy patch test in diagnosing hypersensitivity to cow's milk and hen's egg in unselected children with and without atopic dermatitis. J Am Acad Dermatol. 2004;5:556-62. 
Patel S M, Keneth R, Falchuk, K. Three brothers with dysphagia caused by eosinophilia esophagitis. Gastrointestinal Endoscopy.2005;61:65-67.

Pepys J. Skin testing. Br J Hosp Med. 1975;14:412.

Powell N, Walker MM,Talley NJ. Gastrointestinal eosinophils in health, disease and functional disorders. Nat Rev. Gastroenterol Hepatol. 2010;7:146-56.

Prasad GA, Alexander JA, Schleck CD, Zinsmeister AR, Smyrk TC, Elias RM Locke GR 3rd, Talley NJ. Epidemiology of eosinophilic esophagitis over three decades in Olmsted County Minnesota. Clin Gastroenterol Hepatol. 2009;7:1055-61.

Prescott SL, Martino D, Hodder M, Richman T, Tulic MK. Progress in Understanding Postnatal Immune Dysregulation in Allergic Disease. World Allergy Organization J. 2010;3:162-6.

Rancé $F$, Juchet A, Brémont F, Dutau G. Correlations between skin prick tests using commercial extracts and fresh foods, specific $\lg E$, and food challenges. Allergy. 1997;52:1031-5.

Rancé F. Food Allergy in children suffering from atopic eczema. Peditr Allergy Immunol. 2008:19:279-84

Rancé F. What is the optimal occlusion time for the atopy patch test in the diagnosis of food allergies in children with atopic dermatitis? Pediatr Allergy Immunol. 2004;15:93-6.

Ring J, Kunz B, Bieber T, et al. The atopy patch test with aeroallergens in atopic eczema. J Allergy Clin Immunol. 1989;82:195.

Ronchetti R, Jesenak M, Trubacova D, Pohanka V, Villa MP. Epidemiology of atopy patch tests with food and inhalant allergens in an unselect population of children. Pediatr Allergy Immunol. 2008;19:599-604. 
Sampson HA. Food Allergy. J Allergy Clin Immunol. 2003:111:s540-7

Sampson HA. Food allergy. Parte1: Immunopathogenesis and clinical disorders. J Allergy Clin Immunol.1999:103:717-28.

Sampson HA. Update on food allergy. J Allergy Clin Immunol.2004;113:80519.

Seidenari S, Manzini BM, Danese P, Giannetti A. Positive patch test to whole mite culture and purified mite extracts in patients with atopic dermatitis, asthma and rhinitis. Ann Allergy. 1992:69:201-6.

Sicherer SH, Furlong TJ, Maes HH Desnick RJ, Sampson HA, Gelb BD. Genetics of peanut allergy: a twin study. J Allergy Clin Immunol. 2000;110:972-84.

Sicherer SH, Noone AS, Munoz-Furlong A . The impact of childhood food allergy on quality of life. Ann Allergy Asthma Immunol. 2001;87:461-464.

Sicherer SH, Sampson HA. Food allergy. J Allergy Clin Immunol. 2006;117:S470-5.

Skripak JM, Matsui EC, Mudd K, Wood RA. The natural hidtory of IgEmediated cow's milk allergy. J Allergy Clim Immunol 2007;120(5):117-7.

Soury D, Barratt G, Ah-Leung Setal. Skin localization of cow's milk proteins delivered by a new ready-to-use atopy patch test. Pharmaceut Res. 2005;22:1530-6.

Spergel JM, Beausoleil JL, Mascarenahs M, Liacouras CA. The use of skin prick test and patch test to identify causative foods in eosinophilic esophagitis. J Allergy Clin Immunol. 2002;109:363-8.

Spergel JM, Book WM, Mays E, Song L, Shah SS, Talley NJ, Bonis PA. Variation in prevalence, diagnostic criteria, and initial management options for eosinophilic gastrointestinal diseases in the United States. J Pediatr Gastroenterol Nutr. 2011;52:300-6. 
Spergel JM. Eosinophilic esophagitis in adults and children: evidence for a food allergy component in many patients. Curr Opin Allergy Clin Immunol. 2007;7:274-8.

Spergel JM; Beausoleil Jl; Mascarenhas M; Liacouras CA. The use of skin prick tests and patch test to identify causative foods in eosinophilic esophagitis. J Allergy Clin Immunol. 2002;109:363-8.

Spergel JM, Brown-Wetehorm T, Beausoleil JL, Shuker M, Liacouras CA. Predictive values for skin prick test and atopy patch test for eosinophilic esophagitis. J Allergy Clin Immunol. 2007;119:509-11.

Solé, D et al. Consenso Brasileiro sobre Alergia Alimentar: 2007. Documento conjunto elaborado pela Sociedade Brasileira de Pediatria e Associação Brasileira de Alergia e Imunopatologia. Rev Bras Alerg Imunopatol. 2008;31:64-89.

Straumann A, Bauer M, Fischer B, Blaser K\& Simon HU. Idiopathic eosinophilic esophagitis is associated with a $\mathrm{TH} 2$-type allergic inflamatory response. J Allergy Clin Immunol. 2001;108,954-61.

Stromberg L. Diagnostic accuracy of the atopy patch test and the skin- prick test for the diagnosis of food allergy in young children with atopic eczema/ dermatitis sybdrome. Acta Paediatr. 2002;91:1044-9.

Talley NJ, Shorter RG, Phillips SF, Zinsmeister AR. Eosinophilic gastroenritis: a clinicopathological study of patients with disease of the mucosae,muscle layer,and subserosal tissues. Gut. 1990;3154-8.

Thepen T, Langeveld- Wildschut EG, Bihari IC, van Wichen DF, van Reijsen FC, Mudde GC, Bruijnzeel-Koomen CA. Biphasic response against aeroallergen in atopic dermatitis showing a switch from an initial $\mathrm{TH} 2$ response to a $\mathrm{TH} 1$ response in situ: an immunocytochemial study. J Allergy Clin Immunol. 1996;97:828-37. 
Turjanmaa K, Darsonw U, Niggemann B, Rancé F, Vanto T, Werfel T. EAACI/ GA LEN Position paper: Present status of the atopy patch test. Allergy. 2006;61:1377-84.

Van Reijsen FC; Bruijnzeel- Koomen CAFM, Kalthoff FS; Maggi E, Romagnani S, Westland JKT, Mudde GC. Skin- derived aeroallergen-specific $\mathrm{T}$ cell clones of $\mathrm{TH} 2$ phenotype in patients with atopic dermatitis. J Allergy Clin Immunol.1992;90:184-92.

Vandenplas Y, Koletzko S, Isolauri E, Hill D, Oranje AP, Brueton M, Staiano A, Dupont C. Guidelines for the diagnosis and management of cow's milk protein allergy in infants. Arch Dis Child. 2007;92:902-8.

Vanto T, Juntunen-Backman K, Varjonen E, Kalimo K, Klemola T, Koivikko A, Koskinen P, Syvänen P, Valovirta E, Varjonen E. The patch test, skin prick test, and serum milk-specific IgE as diagnostic tools in cow's milk allergy in infants. Allergy. 1999;54:837-42.

Wahn U, Von Mutius E. Childhood risk factors for atopy and the importance of early intervention. J Allergy Clin Immunol. 2001;107:567-74

Wal JM. Bovine milk allergenicity. Ann Allergy Asthma Immunol. 2004;(Suppl 3):S2-S11.

Wang J, Sampson HA. Food anaphylaxis. Clin Exp Allergy. 2007;37;651-60.

Weissenbacher S, Traidi- Hoffmann C, Eyerich K, Katzer K, Brautigam M, Loeffler H, Hofmann H, Behrendt H, Ring J, Darsow U. Modulation of atopy patch test and skin prick test by pretreatment with $1 \%$ pimecrolimus cream. Int Arch Allergy Immunol. 2006;140:239-44.

Werfel T, Ballmer-Weber B, Eigenmann PA, Niggemann B, Rancé F, Turjanmaa K, Worm M. Eczematous reactions to food in atopic eczema: position paper of the EAACI and GA2LEN. Allergy. 2007;62:723-8.

Wide L, Bennich H, Johansson SGO. Diagnosis of allergy by an in vitro test for allergen antibodies. Lancet. 1967;2:1105-7. 
Williams LW, Bock SA. Skin testing and food challenges in allergy and immunology practice. Clin Rev Allergy Immunol.1999:17: 323-38.

Wolfe JL, Aceves SS. Gastrointestinal Manifestations of Food Allergies. Pediatr Clin N AM.2011;58:389-405.

Wood R. The Natural History of Food Allergy. Pediatrics. 2003;111:6.

Yan BM, Shaffer EA. Primary eosinophilic disorders of the gastrointestinal tract. Gut. 2009;58:721-32. 